Article

\title{
Synthesis, Structural Characterization and Biological Activity of Novel Cyclohexane-1,3-dione Ligands and Their Metal Complexes
}

\author{
Nevin Turan ${ }^{1, *}$, Hanifi Körkoca ${ }^{2}$, Ragıp Adigüzel ${ }^{3}$, Naki Çolak ${ }^{4}$ and Kenan Buldurun ${ }^{1}$ \\ 1 Department of Chemistry, Faculty of Arts and Sciences, Muş Alparslan University, 49250 Muş, \\ Turkey; E-Mail: k.buldurun@alparslan.edu.tr \\ 2 Nursing Department, School of Health, Muş Alparslan University, 49250 Muş, Turkey; \\ E-Mail: h.korkoca@alparslan.edu.tr \\ 3 Department of Chemical Engineering, Faculty of Engineering, Tunceli University, 62000 Tunceli, \\ Turkey; E-Mail: radiguzel@tunceli.edu.tr \\ 4 Department of Chemistry, Faculty of Arts and Sciences, Hitit University, 19100 Çorum, Turkey; \\ E-Mail: nakicolak@hitit.edu.tr
}

* Author to whom correspondence should be addressed; E-Mail: nevintrn@hotmail.com or n.turan@alparslan.edu.tr; Tel.: +90-4362494949 (ext. 3007); Fax: +90-4362130054.

Academic Editor: Derek J. McPhee

Received: 1 April 2015 / Accepted: 15 May 2015 /Published: 21 May 2015

\begin{abstract}
Some new $\mathrm{Zn}(\mathrm{II})$ and $\mathrm{Cu}(\mathrm{II})$ complexes $\left[\mathrm{Cu}\left(\mathrm{L}^{1}\right)(\mathrm{OAc})_{2}\right] \cdot \mathrm{H}_{2} \mathrm{O}$, $\left[\mathrm{Cu}\left(\mathrm{L}^{1}\right)\left(\mathrm{NO}_{3}\right) \mathrm{H}_{2} \mathrm{O}\right] \cdot \mathrm{NO}_{3} \cdot 3.5 \mathrm{H}_{2} \mathrm{O}, \quad\left[\mathrm{Zn}\left(\mathrm{L}^{1}\right)\left(\mathrm{NO}_{3}\right)_{2}\right] \cdot 4.5 \mathrm{H}_{2} \mathrm{O}, \quad\left[\mathrm{Zn}\left(\mathrm{L}^{1}\right)(\mathrm{OAc})_{2}\left(\mathrm{H}_{2} \mathrm{O}\right)_{2}\right] \cdot 3 \mathrm{H}_{2} \mathrm{O}$, $\left[\mathrm{Cu}_{2}\left(\mathrm{~L}^{2}\right)(\mathrm{OAc})_{4}\right] \cdot 2 \mathrm{H}_{2} \mathrm{O} \cdot 2 \mathrm{DMF},\left[\mathrm{Cu}\left(\mathrm{L}^{2}\right)_{2}\right] \cdot 2 \mathrm{NO}_{3} \cdot 1.5 \mathrm{DMF} \cdot \mathrm{H}_{2} \mathrm{O},\left[\mathrm{Zn}\left(\mathrm{L}^{2}\right)_{2}\left(\mathrm{NO}_{3}\right)_{2}\right] \cdot \mathrm{DMF}$ and $\left[\mathrm{Zn}_{2}\left(\mathrm{~L}^{2}\right)(\mathrm{OAc})_{4}\left(\mathrm{H}_{2} \mathrm{O}\right)_{4}\right] \cdot 5 \mathrm{H}_{2} \mathrm{O} ; \mathrm{L}^{1}=$ 2-[2-(2-methoxyphenyl)hydrazono]cyclohexane-1,3-

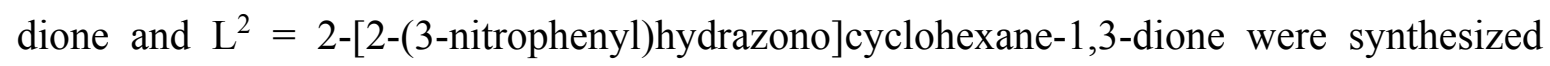
and characterized by IR, ${ }^{1} \mathrm{H}-\mathrm{NMR},{ }^{13} \mathrm{C}-\mathrm{NMR}$ and ultraviolet (UV-Vis.) spectroscopy, elemental analysis, magnetic susceptibility, mass spectrometry and thermogravimetrydifferential thermal analysis (TGA-DTA). The synthesized ligands and their complexes were tested for antibacterial activity against Escherichia coli ATCC 25922, Enterococcus faecalis ATCC 29212, Staphylococcus aureus ATCC 25923, and Salmonella typhimurium CCM 583. Some of complexes showed medium-level antibacterial activity against the test bacteria compared with ampicillin.
\end{abstract}


Keywords: cyclohexane-1,3-dione; antibacterial activity; metal complexes; mass spectra; spectroscopic characterization

\section{Introduction}

Cyclohexane-1,3-dione and its derivatives are important building blocks. The cyclohexane-1,3dione skeleton is a characteristic molecular fragment common for a class of natural and synthetic herbicides and drugs inhibiting 4-hydroxyphenylpyruvate deoxygenase [1,2]. The inhibitory properties of this class of compounds are a result of their ability to chelate the ferrous ion in the active site of the enzyme.

Arylhydrazones of mono-, di- and triketones as well as cyclic 1,3-diones viz., cyclohexane-1,3dione have been reported in the literature. Such compounds have been extensively used as precursors of potential anti-diabetic drugs [3]. Hydrazones are compounds whose molecules contain the $\mathrm{C}=\mathrm{N}-\mathrm{NH}$ - triatomic linkage. The biological, chemical and industrial versatility of hydrazones and their complexes continue to attract considerable attention [4,5]. The role of hydrazones in treating tuberculosis is well known. Substituted hydrazones have established spasmolytic activity, activity against leukemia, and sarcomas [6]. Also they possess anti-inflammatory, analgesic, antipyretic, antibacterial and antitumor activities [7].

In order to investigate the relationship of ligands $\mathrm{L}^{1}$ and $\mathrm{L}^{2}$ and their complexes with their biological activities, we synthesized two new ligand, 2-[2-(2-methoxyphenyl)hydrazono]cyclohexane1,3-dione $\left(\mathrm{L}^{1}\right)$ 2-[2-(3-nitrophenyl)hydrazono]cyclohexane-1,3-dione $\left(\mathrm{L}^{2}\right)$. Then, their $\mathrm{Zn}(\mathrm{II})$ and $\mathrm{Cu}(\mathrm{II})$ complexes were synthesized by reaction of $\mathrm{Zn}\left(\mathrm{NO}_{3}\right)_{2} \cdot 6 \mathrm{H}_{2} \mathrm{O}, \mathrm{Cu}\left(\mathrm{NO}_{3}\right)_{2} \cdot 2 \mathrm{H}_{2} \mathrm{O}, \mathrm{Zn}(\mathrm{OAc})_{2} \cdot 2 \mathrm{H}_{2} \mathrm{O}$ and $\mathrm{Cu}(\mathrm{OAc})_{2} \cdot \mathrm{H}_{2} \mathrm{O}$, respectively. The structure of the ligands is shown in Figure 1. Finally, all of the synthesized compounds were tested for their antibacterial activities against Escherichia coli ATCC 25922 (non- $\beta$-lactamase producing), vancomycin susceptible Enterococcus faecalis ATCC 29212, methicillin susceptible Staphylococcus aureus ATCC 25923, and Salmonella typhimurium CCM 583.

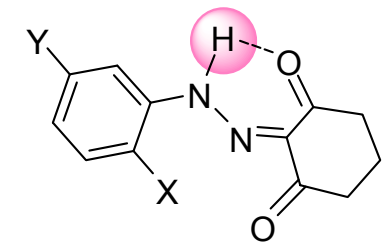

\begin{tabular}{|ccc|}
\hline Ligand: & $\mathrm{L}^{1}$ & $\mathrm{~L}^{2}$ \\
\hline $\mathrm{X}:$ & $\mathrm{OCH}_{3}$ & - \\
\hline $\mathrm{Y}:$ & - & $\mathrm{NO}_{2}$ \\
\hline
\end{tabular}

Figure 1. Structures of the ligands $\mathrm{L}^{1}$ and $\mathrm{L}^{2}$. 


\section{Results and Discussion}

\subsection{Infrared Spectra}

IR absorptions of both $\mathrm{L}^{1}$ and $\mathrm{L}^{2}$ and their metal complexes along with assignments are summarized in the experimental section. All complexes are air stable and insoluble in most organic solvents and water, but freely soluble in coordinating solvents such as pyridine, DMF or DMSO. All have higher melting or decomposition points than the parent ligands.

In the IR spectrum of $\mathrm{L}^{1}$ the characteristic peaks are seen at $2955-3500 \mathrm{~cm}^{-1} \mathrm{v}(\mathrm{NH}), 1280 \mathrm{~cm}^{-1}$ $v\left(\mathrm{OCH}_{3}\right), 1696,1671 \mathrm{~cm}^{-1} v(\mathrm{C}=\mathrm{O})$, and $1505 \mathrm{~cm}^{-1} v(\mathrm{C}=\mathrm{C})[8,9-11]$. The $\mathrm{L}^{1}$ shows a broad $\mathrm{NH}$ band at $3343 \mathrm{~cm}^{-1}$ due to the hydrazone NH group. The position and broadness of the band are indicative of intramolecular hydrogen bonding between the hydrazone proton and the carbonyl oxygen. The hydrazone can coordinate to transition metals either in the enolic form $(\mathrm{N}=\mathrm{N}-\mathrm{C}=\mathrm{C}-\mathrm{OH})$ or in ketonic form $(\mathrm{HN}-\mathrm{N}=\mathrm{C}-\mathrm{C}=\mathrm{O})$. In $\mathrm{L}^{1}$ and $\mathrm{L}^{2}$ the characteristic hydrazone group $>\mathrm{CONH}-$ peaks indicate that the ligand exists in the keto form in the solid state. This $\mathrm{NH}$ band shifted upon complexation of the ligand with metals due to coordination of the hydrazone proton in $\left[\mathrm{Cu}_{2}\left(\mathrm{~L}^{2}\right)(\mathrm{OAc})_{4}\right] \cdot 2 \mathrm{H}_{2} \mathrm{O} \cdot 2 \mathrm{DMF}$ and all of the $\mathrm{Zn}(\mathrm{II})$ complexes $[12,13]$.

The strong bands at 1696,1671 and $1686 \mathrm{~cm}^{-1}$, in the spectra of $\mathrm{L}^{1}$ and $\mathrm{L}^{2}$, respectively, may be assigned to $v(\mathrm{C}=\mathrm{O})$. In the spectra of all complexes, except those of $\left[\mathrm{Zn}\left(\mathrm{L}^{1}\right)\left(\mathrm{NO}_{3}\right)_{2}\right] \cdot 4.5 \mathrm{H}_{2} \mathrm{O}$, $\left[\mathrm{Zn}\left(\mathrm{L}^{1}\right)(\mathrm{OAc})_{2}\left(\mathrm{H}_{2} \mathrm{O}\right)_{2}\right] \cdot 3 \mathrm{H}_{2} \mathrm{O}$ and $\left[\mathrm{Zn}\left(\mathrm{L}^{2}\right)_{2}\left(\mathrm{NO}_{3}\right)_{2}\right] \cdot \mathrm{DMF}$, these bands are found to be shifted to lower frequency, indicating the participation of the carbonyl oxygen in coordination. Peaks at $1671,1686 \mathrm{~cm}^{-1}$ $v(\mathrm{C}=\mathrm{O}), 1626,1633 \mathrm{~cm}^{-1} v(\mathrm{C}=\mathrm{O} \ldots . \mathrm{H})$ and $1592 \mathrm{~cm}^{-1} v(\mathrm{C}=\mathrm{N})$ also support the H-bonded hydrazone structure in the solid state [14]. In the $\left[\mathrm{CuL}^{1}\left(\mathrm{NO}_{3}\right) \mathrm{H}_{2} \mathrm{O}\right] \cdot \mathrm{NO}_{3} \cdot 3.5 \mathrm{H}_{2} \mathrm{O}$ and $\left[\mathrm{Cu}\left(\mathrm{L}^{2}\right)_{2}\right] \cdot 2 \mathrm{NO}_{3} \cdot 1.5 \mathrm{DMF} \cdot \mathrm{H}_{2} \mathrm{O}$ complexes, bands appearing at 1384 and $1382 \mathrm{~cm}^{-1}$, respectively, suggest the presence of ionic nitrate in the complexes [14].

In the IR spectrum of $\mathrm{L}^{2}$, the characteristic peaks are at 1686 and $1353 \mathrm{~cm}^{-1}$, which are assigned to $v(\mathrm{C}=\mathrm{O})$ and $v\left(\mathrm{NO}_{2}\right)$, and at $1614 \mathrm{~cm}^{-1}$ which is assigned to the $v(\mathrm{C}=\mathrm{N})$ group $[15,16]$. In addition, the spectrum of the ligand $\mathrm{L}^{2}$ shows broad bands in the $3500-3100 \mathrm{~cm}^{-1}$ region, which may be assigned to a $v(\mathrm{NH})$ band. In the IR spectra of $\mathrm{L}^{2}$, the bands assigned to $v(\mathrm{C}=\mathrm{O})$ and $v(\mathrm{C}=\mathrm{N})$ are shifted by $\pm 16-35 \mathrm{~cm}^{-1}$ in the spectra of complexes, indicating coordination through the exocyclic carbonyl oxygen and $\mathrm{C}=\mathrm{N}$ nitrogen of $\mathrm{L}^{2}$. In the spectra of the metal complexes of the $\mathrm{L}^{2}$, the band at $1353 \mathrm{~cm}^{-1}$ for the $\mathrm{NO}_{2}$ group did not shift [17], showing that in these complexes the $\mathrm{NO}_{2}$ group did not participate in complex formation. In the IR spectra of the complexes, $v\left(\mathrm{OCH}_{3}\right)$ remains unmodified, indicating that the methoxy group is also not involved in the coordination.

The infrared spectra of all complexes, except that of $\left[\mathrm{Zn}\left(\mathrm{L}^{2}\right)_{2}\left(\mathrm{NO}_{3}\right)_{2}\right] \cdot \mathrm{DMF}$ complex, exhibited intense broad bands at $3560-3311 \mathrm{~cm}^{-1}$ that are attributed to $v(\mathrm{OH})$ of the lattice or coordinated water molecules, while the $v\left(\mathrm{H}_{2} \mathrm{O}\right)$ bands observed at approximately $876-764 \mathrm{~cm}^{-1}$ are assigned to coordinated water molecules [18-20]. The spectra of the complexes show a few new absorption bands in the $491-455 \mathrm{~cm}^{-1}$ and $585-510 \mathrm{~cm}^{-1}$ ranges, assigned to $v(\mathrm{M}-\mathrm{N})$ and $v(\mathrm{M}-\mathrm{O})$, respectively.

The complexes $\left[\mathrm{Cu}\left(\mathrm{L}^{1}\right)\left(\mathrm{NO}_{3}\right) \mathrm{H}_{2} \mathrm{O}\right] \cdot \mathrm{NO}_{3} \cdot 3.5 \mathrm{H}_{2} \mathrm{O}, \quad\left[\mathrm{Zn}\left(\mathrm{L}^{1}\right)(\mathrm{OAc})_{2}\left(\mathrm{H}_{2} \mathrm{O}\right)_{2}\right] \cdot 3 \mathrm{H}_{2} \mathrm{O} \quad$ and $\left[\mathrm{Zn}_{2}\left(\mathrm{~L}^{2}\right)(\mathrm{OAc})_{4}\left(\mathrm{H}_{2} \mathrm{O}\right)_{4}\right] \cdot 5 \mathrm{H}_{2} \mathrm{O}$ show a broad band at $3468-3311 \mathrm{~cm}^{-1}$ indicating the coordination of water to the metal ion. From the IR results, it may be concluded that the $\mathrm{L}^{1}$ and $\mathrm{L}^{2}$ ligands are bi- or 
tridentate and coordinate with the metal ions through the carbonyl oxygen, hydrazone nitrogen and/or acetic acid oxygen atoms.

The $v(\mathrm{~N}-\mathrm{N})$ bands of the $\mathrm{L}^{1}$ and $\mathrm{L}^{2}$ ligands at $1025,1010 \mathrm{~cm}^{-1}$ are found to be shifted to higher energies $\left(1041-1020 \mathrm{~cm}^{-1}\right)$ in the spectra of the complexes, indicating coordination via the nitrogen atoms. This is confirmed by bands in the range of 491-455 $\mathrm{cm}^{-1}$, which have been assigned to the $v(\mathrm{Zn}-\mathrm{N}) v(\mathrm{Cu}-\mathrm{N})$ bands [21].

The IR spectra of the $\left[\mathrm{Cu}_{2}\left(\mathrm{~L}^{2}\right)(\mathrm{OAc})_{4}\right] \cdot 2 \mathrm{H}_{2} \mathrm{O} \cdot 2 \mathrm{DMF}, \quad\left[\mathrm{Cu}\left(\mathrm{L}^{2}\right)_{2}\right] \cdot 2 \mathrm{NO}_{3} \cdot 1.5 \mathrm{DMF} \cdot \mathrm{H}_{2} \mathrm{O}$ and $\left[\mathrm{Zn}\left(\mathrm{L}^{2}\right)_{2}\left(\mathrm{NO}_{3}\right)_{2}\right] \cdot \mathrm{DMF}$ complexes show strong bands around $1660 \mathrm{~cm}^{-1}$ assigned to a $v(\mathrm{C}=\mathrm{O})$ vibration of the DMF molecules [22]. The IR spectra of $\left[\mathrm{Cu}\left(\mathrm{L}^{1}\right)(\mathrm{OAc})_{2}\right] \cdot 5 \mathrm{H}_{2} \mathrm{O},\left[\mathrm{Zn}\left(\mathrm{L}^{1}\right)(\mathrm{OAc})_{2}\left(\mathrm{H}_{2} \mathrm{O}\right)_{2}\right] \cdot 3 \mathrm{H}_{2} \mathrm{O}$, $\left[\mathrm{Cu}_{2}\left(\mathrm{~L}^{2}\right)(\mathrm{OAc})_{4}\right] \cdot 2 \mathrm{H}_{2} \mathrm{O} \cdot 2 \mathrm{DMF}$ and $\left[\mathrm{Zn}_{2}\left(\mathrm{~L}^{2}\right)(\mathrm{OAc})_{4}\left(\mathrm{H}_{2} \mathrm{O}\right)_{4}\right] \cdot 5 \mathrm{H}_{2} \mathrm{O}$ show two new bands at 1555 and $1384 \mathrm{~cm}^{-1}$ assignable to the $v_{\mathrm{as}}(\mathrm{C}-\mathrm{O})$ and $v_{\mathrm{s}}(\mathrm{C}-\mathrm{O})$ bands of the acetate group $[23,24]$, respectively, which are consistent with monodentate acetate coordination. The IR spectra of the $\left[\mathrm{Cu}\left(\mathrm{L}^{1}\right)\left(\mathrm{NO}_{3}\right) \mathrm{H}_{2} \mathrm{O}\right] \cdot \mathrm{NO}_{3} \cdot 3.5 \mathrm{H}_{2} \mathrm{O},\left[\mathrm{Zn}\left(\mathrm{L}^{1}\right)\left(\mathrm{NO}_{3}\right)_{2}\right] \cdot 4.5 \mathrm{H}_{2} \mathrm{O}$ and $\left[\mathrm{Zn}\left(\mathrm{L}^{2}\right)_{2}\left(\mathrm{NO}_{3}\right)_{2}\right] \cdot \mathrm{DMF}$ complexes show strong bands at 1385 and $1285 \mathrm{~cm}^{-1}$ assigned to $v_{\text {as }}\left(\mathrm{NO}_{3}{ }^{-}\right)$and $v_{\mathrm{s}}\left(\mathrm{NO}_{3}{ }^{-}\right)$, respectively, indicating the presence of terminally bounded monodentate nitrate groups $[25,26]$.

\section{2. ${ }^{1} \mathrm{H}-\mathrm{NMR}$ and ${ }^{13} \mathrm{C}-\mathrm{NMR}$ Spectra}

The ${ }^{1} \mathrm{H}-\mathrm{NMR}$ spectra of $\mathrm{L}^{1}, \mathrm{~L}^{2}$ and their $\mathrm{Zn}(\mathrm{II})$ complexes were recorded in dimethylsulfoxide (DMSO-d6) solution using tetramethylsilane (TMS) as internal standard. The ${ }^{1} \mathrm{H}-\mathrm{NMR}$ spectrum of $\mathrm{L}^{1}$ shows a singlet at $4.00 \mathrm{ppm}$ that may be assigned to the protons of the methoxy group, a singlet at $15.00 \mathrm{ppm}$ that may be assigned to the proton of the NH group, a multiplet at 7.20-7.80 ppm that may be assigned to the aromatic protons and another at 2.00-2.70 ppm that may be assigned to the hexane ring protons. Similar peaks are observed for the ligand $\mathrm{L}^{2}$. The ${ }^{1} \mathrm{H}-\mathrm{NMR}$ spectrum of the diamagnetic $\mathrm{Zn}$ (II) complexes shows almost the same values as the ligands. The signals due to the -NH proton are shifted downfield in the spectra of the $\mathrm{Zn}$ (II) complexes, indicating the coordination of the ligand through the nitrogen of the -NH groups to the metal ions. The hydrogen bonding decreases the electron density around the proton and thus moves the proton absorption to a lower field [27]. In addition, $\mathrm{H}_{2} \mathrm{O}$ and acetate proton signals are seen in NMR spectra of complexes.

\subsection{Electronic Spectra and Magnetic Properties}

The electronic spectra of $\mathrm{L}^{1}, \mathrm{~L}^{2}$ and their metal complexes were recorded in $3 \times 10^{-3}$ molar DMF solutions in the range from 200 to $800 \mathrm{~nm}$. The electronic spectrum of the ligands shows broad bands at 218,242 and $316-393 \mathrm{~nm}$; the first two absorption bands may be assigned to $\mathrm{n} \rightarrow \pi^{*}$ and $\pi \rightarrow \pi^{*}$ transitions of $>\mathrm{C}=\mathrm{O}$ and $>\mathrm{C}=\mathrm{N}$ moieties [28], the third absorption band may be due to high-intensity charge transfer transitions.

The $\left[\mathrm{Cu}\left(\mathrm{L}^{1}\right)(\mathrm{OAc})_{2}\right] \cdot 5 \mathrm{H}_{2} \mathrm{O}$ complex shows square-planar geometry. It shows intense absorption bands in the 254-269 and $414 \mathrm{~nm}$ range which can be assigned to the $\pi \rightarrow \pi^{*}$ transition of the $\mathrm{C}=\mathrm{N}$ or $\mathrm{C}=\mathrm{O}$ groups and charge-transfer bands, respectively. The electronic spectrum of the complex shows an absorption band in the range $580 \mathrm{~nm}$, attributed to ${ }^{2} \mathrm{~T}_{2 \mathrm{~g}} \rightarrow{ }^{2} \mathrm{E}_{\mathrm{g}}$ transition suggesting a square-planar geometry [29]. 
The electronic absorption spectrum of the $\left[\mathrm{Cu}\left(\mathrm{L}^{1}\right)\left(\mathrm{NO}_{3}\right) \mathrm{H}_{2} \mathrm{O}\right] \cdot \mathrm{NO}_{3} \cdot 3.5 \mathrm{H}_{2} \mathrm{O}$ complex in DMSO solution shows three bands at 254-295, 353, 393 and $428-450 \mathrm{~nm}$, assignable to the ${ }^{2} \mathrm{~B}_{1 \mathrm{~g}} \rightarrow{ }^{2} \mathrm{~B}_{2 \mathrm{~g}}$, ${ }^{2} \mathrm{~B}_{1 \mathrm{~g}} \rightarrow{ }^{2} \mathrm{E}_{\mathrm{g}}$, and ${ }^{2} \mathrm{~B}_{1 \mathrm{~g}} \rightarrow{ }^{2} \mathrm{~A}_{1 \mathrm{~g}}$ transitions and two intra-ligand charge transfer bands. These data and the magnetic moment value of 1.72 B.M. suggest square-planar geometry around $\mathrm{Cu}(\mathrm{II})$ [30,31].

Square planar geometry is suggested for $\left[\mathrm{Cu}_{2}\left(\mathrm{~L}^{2}\right)(\mathrm{OAc})_{4}\right] \cdot 2 \mathrm{H}_{2} \mathrm{O} \cdot 2 \mathrm{DMF}$ from the presence of bands at 600 and $454 \mathrm{~nm}$ for the complex. These bands are assigned to the ${ }^{2} \mathrm{~B}_{1 \mathrm{~g}} \rightarrow{ }^{2} \mathrm{~A}_{1 \mathrm{~g}}$ and ${ }^{2} \mathrm{~B}_{1 \mathrm{~g}} \rightarrow{ }^{2} \mathrm{Eg}_{\mathrm{g}}$ transitions, while the second band is due to charge transfer. The magnetic moment values for the $\mathrm{Cu}$ (II) complex are normal and lower (1.66 B.M.) than expected 1.7-2.2 B.M. for one unpaired electron [32,33].

The electronic spectrum of $\mathrm{Cu}(\mathrm{II})$ complex shows bands in the regions of 254, 376 and $470 \mathrm{~nm}$ which may be assigned to the ${ }^{2} \mathrm{~B}_{1 \mathrm{~g}} \rightarrow{ }^{2} \mathrm{~A}_{1 \mathrm{~g}}$ transitions in a square-planar geometry. The magnetic moment value of $\left[\mathrm{Cu}\left(\mathrm{L}^{2}\right)_{2}\right] \cdot 2 \mathrm{NO}_{3} \cdot 1.5 \mathrm{DMF} \cdot \mathrm{H}_{2} \mathrm{O}$ complex is $2.22 \mathrm{~B} . \mathrm{M}$. [34].

The electronic spectra of the $\mathrm{Zn}$ (II) complexes show only a high-intensity band at $357-425 \mathrm{~cm}^{-1}$ assigned to ligand-metal charge transfer.

\subsection{Thermal Studies}

The thermal stability of the ligands and complexes is investigated using thermogravimetric analysis. The TGA curves are obtained at a heating rate of $10{ }^{\circ} \mathrm{C} \cdot \mathrm{min}^{-1}$ under a nitrogen atmosphere in a temperature range of $25.0-800.0^{\circ} \mathrm{C}$. The results obtained are in good agreement with the theoretical formula suggested from the elemental analyses. The thermal data are summarized in Table 1.

The $\left[\mathrm{Cu}_{2}\left(\mathrm{~L}^{1}\right)_{2}(\mathrm{AcO})_{2}\right] \cdot 5 \mathrm{H}_{2} \mathrm{O}$ complex is stable up to $95{ }^{\circ} \mathrm{C}$ and its decomposition starts at this temperature. A $16.92(17.39 \%)$ weight loss is observed at $195{ }^{\circ} \mathrm{C}$ corresponding to five moles of water of crystallization. The DTA curve of the complex shows one endothermic peak at $350.50-360.00{ }^{\circ} \mathrm{C}$. For the $\mathrm{Cu}(\mathrm{II})$ complex, the DTA curve shows an endothermic process around $350.50{ }^{\circ} \mathrm{C}$ that corresponds to the rupture of the coordinated bond and simultaneous melting of the complex [35].

The $\left[\mathrm{Cu}\left(\mathrm{L}^{1}\right)\left(\mathrm{NO}_{3}\right) \mathrm{H}_{2} \mathrm{O}\right] \cdot \mathrm{NO}_{3} \cdot 3.5 \mathrm{H}_{2} \mathrm{O}$ complex was stable up to $85{ }^{\circ} \mathrm{C}$ and its decomposition started at this temperature. The first decomposition stage at $160{ }^{\circ} \mathrm{C}$ is attributed to the removal of 3.5 moles of water of crystallization and 1 mole of nitrate ion with a 24.62(24.29\%) loss. The second weight loss stage of $234.48-494.55{ }^{\circ} \mathrm{C}$ corresponds to the removal of the $\mathrm{H}_{2} \mathrm{O}, \mathrm{NO}_{3}{ }^{-}$and $\mathrm{C}_{6} \mathrm{H}_{6} \mathrm{O}_{2} \mathrm{~N}$ as a fragment of the ligand decomposition. The DTA curve of the $\mathrm{Cu}(\mathrm{II})$ complex shows two endothermic peaks at $150.10^{\circ} \mathrm{C}, 380.50{ }^{\circ} \mathrm{C}$ and one exothermic peak at $485.25^{\circ} \mathrm{C}$.

The $\left[\mathrm{Zn}\left(\mathrm{L}^{1}\right)\left(\mathrm{NO}_{3}\right)_{2}\right] \cdot 4.5 \mathrm{H}_{2} \mathrm{O}$ complex decomposed in three stages. In the first stage, loss of 4.5 moles of water of crystallization and in the second stage, loss of two moles of $\mathrm{NO}_{3}{ }^{-}$and $\mathrm{C}_{13} \mathrm{H}_{14} \mathrm{O}_{2} \mathrm{~N}_{2}$ groups resulted. In the third stage, the complex decomposed to $\mathrm{ZnO}$. The DTA curve of the complex shows two endothermic peaks at $450.00-470.20{ }^{\circ} \mathrm{C}$. For the $\mathrm{Zn}$ (II) complex, these peaks corresponds to simultaneous melting of the complex [35].

The $\left[\mathrm{Zn}\left(\mathrm{L}^{1}\right)(\mathrm{OAc})_{2}\left(\mathrm{H}_{2} \mathrm{O}\right)_{2}\right] \cdot 3 \mathrm{H}_{2} \mathrm{O}$ complex decomposed in two stages. The first is due to removal of the crystallization water molecule with a weight loss of $18.76(18.83 \%)$. The second weight loss is associated with the removal of two moles of water as well as $2 \mathrm{C}_{2} \mathrm{H}_{3} \mathrm{O}_{2}{ }^{-}$from the ligand [36]. The DTA curve of the $\mathrm{Zn}$ (II) complex shows two endothermic peaks at $280.10{ }^{\circ} \mathrm{C}, 330.50{ }^{\circ} \mathrm{C}$ and one exothermic peak at $420.25{ }^{\circ} \mathrm{C}$. 
Table 1. Proposed decomposition steps and the respective mass losses of ligands $\left(\mathrm{L}^{1}\right.$ and $\mathrm{L}^{2}$ ) and their complexes.

\begin{tabular}{|c|c|c|c|}
\hline Equations & $\begin{array}{c}\text { Temperature } \\
\left({ }^{\circ} \mathrm{C}\right)\end{array}$ & $\begin{array}{c}\% \text { Loss in Weight } \\
\% \text { Found }(\% \\
\text { Calculated) } \\
\end{array}$ & Decomp. Products \\
\hline \multicolumn{4}{|l|}{$\left[\mathrm{Cu}\left(\mathrm{L}^{1}\right)(\mathrm{OAc})_{2}\right] \cdot 5 \mathrm{H}_{2} \mathrm{O}$} \\
\hline $\mathrm{C}_{17} \mathrm{H}_{30} \mathrm{~N}_{2} \mathrm{O}_{12} \mathrm{Cu}$ & $95.50-250.00$ & $16.92(17.39)$ & $5 \mathrm{H}_{2} \mathrm{O}$ \\
\hline $\mathrm{C}_{17} \mathrm{H}_{20} \mathrm{~N}_{2} \mathrm{O}_{7} \mathrm{Cu}$ & $250.00-514.29$ & $40.00(40.36)$ & $2 \mathrm{OAc}^{-}, \mathrm{C}_{6} \mathrm{H}_{5} \mathrm{~N}$ \\
\hline $\mathrm{C}_{7} \mathrm{H}_{9} \mathrm{NO}_{3} \mathrm{Cu}$ & $514.29-650.00$ & $24.62(23.96)$ & $\mathrm{C}_{6} \mathrm{H}_{6} \mathrm{NO}_{2}$ \\
\hline $\mathrm{CH}_{3} \mathrm{OCu}$ & 650-Cont. & & \\
\hline \multicolumn{4}{|c|}{$\left[\mathrm{Cu}\left(\mathrm{L}^{1}\right)\left(\mathrm{NO}_{3}\right) \mathrm{H}_{2} \mathrm{O}\right] \cdot \mathrm{NO}_{3} \cdot 3.5 \mathrm{H}_{2} \mathrm{O}$} \\
\hline $\mathrm{C}_{13} \mathrm{H}_{16} \mathrm{~N}_{4} \mathrm{O}_{10} \mathrm{Cu} \cdot 3.5 \mathrm{H}_{2} \mathrm{O}$ & $85.25-234.48$ & $24.62(24.29)$ & $3.5 \mathrm{H}_{2} \mathrm{O}, \mathrm{NO}_{3}^{-}$ \\
\hline $\mathrm{C}_{13} \mathrm{H}_{16} \mathrm{~N}_{3} \mathrm{O}_{7} \mathrm{Cu}$ & $234.48-494.55$ & $40.00(39.64)$ & $\mathrm{H}_{2} \mathrm{O}$ and $\mathrm{NO}_{3}{ }^{-}, \mathrm{C}_{6} \mathrm{H}_{6} \mathrm{O}_{2} \mathrm{~N}$ \\
\hline $\mathrm{C}_{7} \mathrm{H}_{8} \mathrm{NOCu}$ & 494.55-Cont. & & \\
\hline \multicolumn{4}{|l|}{$\left[\mathrm{Zn}\left(\mathrm{L}^{1}\right)\left(\mathrm{NO}_{3}\right)_{2}\right] \cdot 4.5 \mathrm{H}_{2} \mathrm{O}$} \\
\hline $\mathrm{C}_{13} \mathrm{H}_{14} \mathrm{~N}_{4} \mathrm{O}_{9} \mathrm{Zn} \cdot 4.5 \mathrm{H}_{2} \mathrm{O}$ & $76.19-457.14$ & $15.39(15.69)$ & $4.5 \mathrm{H}_{2} \mathrm{O}$ \\
\hline $\mathrm{C}_{13} \mathrm{H}_{14} \mathrm{~N}_{4} \mathrm{O}_{9} \mathrm{Zn}$ & $457.14-495.23$ & $67.69(68.55)$ & $2 \mathrm{NO}_{3}{ }^{-}, \mathrm{C}_{13} \mathrm{H}_{14} \mathrm{O}_{2} \mathrm{~N}_{2}$ \\
\hline $\mathrm{ZnO}$ & 495.23-Cont. & & \\
\hline \multicolumn{4}{|l|}{$\left[\mathrm{Zn}\left(\mathrm{L}^{1}\right)(\mathrm{OAc})_{2}\left(\mathrm{H}_{2} \mathrm{O}\right)_{2}\right] \cdot 3 \mathrm{H}_{2} \mathrm{O}$} \\
\hline $\mathrm{C}_{17} \mathrm{H}_{30} \mathrm{~N}_{2} \mathrm{O}_{12} \mathrm{Zn}$ & $80.32-284.75$ & $18.76(18.83)$ & $3 \mathrm{H}_{2} \mathrm{O}$ \\
\hline $\mathrm{C}_{17} \mathrm{H}_{24} \mathrm{~N}_{2} \mathrm{O}_{9} \mathrm{Zn}$ & $284.75-423.50$ & $29.23(29.65)$ & $2 \mathrm{H}_{2} \mathrm{O}$ and $2 \mathrm{C}_{2} \mathrm{H}_{3} \mathrm{O}_{2}^{-}$ \\
\hline $\mathrm{C}_{13} \mathrm{H}_{14} \mathrm{~N}_{2} \mathrm{O}_{3} \mathrm{Zn}$ & 423.50-Cont. & & \\
\hline \multicolumn{4}{|l|}{$\left.\left[\mathrm{Cu}_{2} \mathrm{~L}^{2}\right)(\mathrm{OAc})_{4}\right] \cdot 2 \mathrm{H}_{2} \mathrm{O} \cdot 2 \mathrm{DMF}$} \\
\hline $\mathrm{C}_{26} \mathrm{H}_{41} \mathrm{~N}_{5} \mathrm{O}_{16} \mathrm{Cu}_{2}$ & $180.12-240.32$ & $23.08(22.58)$ & $2 \mathrm{H}_{2} \mathrm{O}$ and $2 \mathrm{DMF}$ \\
\hline $\mathrm{C}_{20} \mathrm{H}_{23} \mathrm{~N}_{3} \mathrm{O}_{12} \mathrm{Cu}_{2}$ & $\begin{array}{c}240.32-285- \\
340\end{array}$ & $29.23(29.27)$ & $4 \mathrm{OAc}^{-}$ \\
\hline $\mathrm{C}_{12} \mathrm{H}_{11} \mathrm{~N}_{3} \mathrm{O}_{4} \mathrm{Cu}_{2}$ & $285-340$ & & \\
\hline \multicolumn{4}{|l|}{$\left[\mathrm{Cu}\left(\mathrm{L}^{2}\right)_{2}\right] \cdot 2 \mathrm{NO}_{3} \cdot 1.5 \mathrm{DMF} \cdot \mathrm{H}_{2} \mathrm{O}$} \\
\hline $\mathrm{C}_{24} \mathrm{H}_{24} \mathrm{~N}_{8} \mathrm{O}_{15} \mathrm{Cu} \cdot 1.5 \mathrm{DMF}$ & $100.05-280.14$ & $24.62(24.79)$ & $\mathrm{H}_{2} \mathrm{O}, 1.5 \mathrm{DMF}, 2 \mathrm{NO}_{3}^{-}$ \\
\hline $\mathrm{C}_{24} \mathrm{H}_{22} \mathrm{~N}_{6} \mathrm{O}_{8} \mathrm{Cu}$ & $280.14-600.00$ & $58.46(58.55)$ & $\mathrm{C}_{24} \mathrm{H}_{22} \mathrm{~N}_{6} \mathrm{O}_{7} \mathrm{Cu}$ \\
\hline \multicolumn{4}{|l|}{$\mathrm{CuO}$} \\
\hline \multicolumn{4}{|l|}{$\left[\mathrm{Zn}\left(\mathrm{L}^{2}\right)_{2}\left(\mathrm{NO}_{3}\right)_{2}\right] \cdot \mathrm{DMF}$} \\
\hline $\mathrm{C}_{24} \mathrm{H}_{22} \mathrm{~N}_{7} \mathrm{O}_{16} \mathrm{Zn}$ & $160.53-241.20$ & $9.23(9.30)$ & DMF \\
\hline $\mathrm{C}_{21} \mathrm{H}_{15} \mathrm{~N}_{6} \mathrm{O}_{15} \mathrm{Zn}$ & $241.20-277.55$ & $44.61(44.10)$ & $2 \mathrm{NO}_{3}^{-}, \mathrm{C}_{12} \mathrm{H}_{14} \mathrm{~N}_{2} \mathrm{O}_{2}$ \\
\hline $\mathrm{C}_{9} \mathrm{HN}_{2} \mathrm{O}_{7} \mathrm{Zn}$ & $277.55-458.33$ & & \\
\hline \multicolumn{4}{|l|}{$\left[\mathrm{Zn}_{2}\left(\mathrm{~L}^{2}\right)(\mathrm{OAc})_{4}\left(\mathrm{H}_{2} \mathrm{O}\right)_{4}\right] \cdot 5 \mathrm{H}_{2} \mathrm{O}$} \\
\hline $\mathrm{C}_{20} \mathrm{H}_{41} \mathrm{~N}_{3} \mathrm{O}_{21} \mathrm{Zn}_{2}$ & $75-120.20$ & $12.30(11.39)$ & $5 \mathrm{H}_{2} \mathrm{O}$ \\
\hline $\mathrm{C}_{20} \mathrm{H}_{31} \mathrm{~N}_{3} \mathrm{O}_{16} \mathrm{Zn}_{2}$ & $120.20-190.55$ & $10.76(9.12)$ & $4 \mathrm{H}_{2} \mathrm{O}$ \\
\hline $\mathrm{C}_{20} \mathrm{H}_{23} \mathrm{~N}_{3} \mathrm{O}_{12} \mathrm{Zn}_{2}$ & $190.55-360.35$ & $29.23(29.87)$ & $4 \mathrm{C}_{2} \mathrm{H}_{3} \mathrm{O}_{2}^{-}$ \\
\hline $\mathrm{C}_{12} \mathrm{H}_{11} \mathrm{~N}_{3} \mathrm{O}_{4} \mathrm{Zn}_{2}$ & 360.35-Cont. & $15.38(15.70)$ & $\mathrm{C}_{6} \mathrm{H}_{6} \mathrm{O}_{2} \mathrm{~N}$ \\
\hline $\mathrm{C}_{6} \mathrm{H}_{5} \mathrm{~N}_{2} \mathrm{O}_{2} \mathrm{Zn}_{2}$ & & & \\
\hline
\end{tabular}


$\left[\mathrm{Cu}_{2}\left(\mathrm{~L}^{2}\right)(\mathrm{OAc})_{4}\right] \cdot 2 \mathrm{H}_{2} \mathrm{O} \cdot 2 \mathrm{DMF}$ shows two decomposition steps. The first decomposition step in the temperature range of $180.12-240.32{ }^{\circ} \mathrm{C}$ may be attributed to the loss of crystallization water molecules and two DMF molecules [36,37]. The second step within the temperature range of $240.32-285.34{ }^{\circ} \mathrm{C}$ 29.23(29.27\%) corresponds to the removal of four moles of acetate molecules as deduced from weight loss calculations. The DTA curve of the $\mathrm{Cu}$ (II) complex shows two endothermic peaks at $160.50{ }^{\circ} \mathrm{C}$ and $190.10^{\circ} \mathrm{C}$. The endothermic peaks are likely due to the loss of water of hydration and DMF molecules.

The complex $\left[\mathrm{Cu}\left(\mathrm{L}^{2}\right)_{2}\right] 2 \mathrm{NO}_{3} \cdot 1.5 \mathrm{DMF} \cdot \mathrm{H}_{2} \mathrm{O}$ is stable up to $100{ }^{\circ} \mathrm{C}$ and its decomposition started at this temperature. In the decomposition process of the $\mathrm{Cu}$ (II) complexes, the mass losses corresponded to one mole $\mathrm{H}_{2} \mathrm{O}, 1.5$ moles DMF and two moles of $\mathrm{NO}_{3}{ }^{-}$in the first stage of the decomposition, respectively. The $\mathrm{Cu}(\mathrm{II})$ complex is stable up to $160.00-240.00{ }^{\circ} \mathrm{C}$ and after this temperature other decomposition ensues. The DTA curve of the $\mathrm{Cu}(\mathrm{II})$ complex shows endothermic peaks at $100.20{ }^{\circ} \mathrm{C}$ and $215.50{ }^{\circ} \mathrm{C}$ corresponding to the loss of $\mathrm{H}_{2} \mathrm{O}, \mathrm{DMF}$ and $\mathrm{NO}_{3}{ }^{-}$and one exothermic peak at $500.10{ }^{\circ} \mathrm{C}$ corresponding to the second weight loss.

The $\left[\mathrm{Zn}_{2}\left(\mathrm{~L}^{2}\right)(\mathrm{OAc})_{4}\left(\mathrm{H}_{2} \mathrm{O}\right)_{4}\right] \cdot 5 \mathrm{H}_{2} \mathrm{O}$ complex followed a four-staged decomposition, in which five moles of water of crystallization, four moles of coordinated water, four moles of acetate ions, and an 2-iminocyclohexane-1,3-dione group and the rest of the ligand decomposed successively. The DTA curve of the $\mathrm{Zn}$ (II) complex shows two endothermic peaks at $130.50{ }^{\circ} \mathrm{C}$ and $180.10{ }^{\circ} \mathrm{C}$. The endothermic peaks are likely due to the loss of molecules of water of hydration.

The decomposition curve of $\left[\mathrm{Zn}\left(\mathrm{L}^{2}\right)_{2}\left(\mathrm{NO}_{3}\right)_{2}\right] \cdot \mathrm{DMF}$ begins with a step at $160.53-241.20{ }^{\circ} \mathrm{C}$, displaying a $9.23(9.30 \%)$ weight loss corresponding to the removal of DMF [38]. The second step within the temperature range of $241.20-277.55^{\circ} \mathrm{C}$ corresponds to the removal of two moles of $\mathrm{NO}_{3}{ }^{-}$ and $\mathrm{C}_{12} \mathrm{H}_{14} \mathrm{~N}_{2} \mathrm{O}_{2}$ groups $44.61(44.10 \%)$ as deduced from weight loss calculations. The DTA curve of the $\mathrm{Zn}$ (II) complex shows one endothermic peak at $170.50{ }^{\circ} \mathrm{C}$ and two exothermic peaks at $300.60{ }^{\circ} \mathrm{C}$ and $350.40{ }^{\circ} \mathrm{C}$. The first one is related to removal of the DMF molecule, whereas the other is the second step of decomposition [18].

The final products formed during thermal analysis of the complexes could not be determined because the decompositions of the complexes were not complete at $800{ }^{\circ} \mathrm{C}$, except for the $\left[\mathrm{Zn}\left(\mathrm{L}^{1}\right)\left(\mathrm{NO}_{3}\right)_{2}\right] \cdot 4.5 \mathrm{H}_{2} \mathrm{O}$ and $\left[\mathrm{Cu}\left(\mathrm{L}^{2}\right)_{2}\right] \cdot 2 \mathrm{NO}_{3} \cdot 1.5 \mathrm{DMF} \cdot \mathrm{H}_{2} \mathrm{O}$ complex.

\subsection{Mass Spectra}

The mass spectra peaks of the $\left[\mathrm{Cu}\left(\mathrm{L}^{1}\right)(\mathrm{OAc})_{2}\right] \cdot 5 \mathrm{H}_{2} \mathrm{O}, \quad\left[\mathrm{Cu}\left(\mathrm{L}^{1}\right)\left(\mathrm{NO}_{3}\right) \mathrm{H}_{2} \mathrm{O}\right] \cdot \mathrm{NO}_{3} \cdot 3.5 \mathrm{H}_{2} \mathrm{O}$, $\left[\mathrm{Zn}\left(\mathrm{L}^{1}\right)(\mathrm{OAc})_{2}\left(\mathrm{H}_{2} \mathrm{O}\right)_{2}\right] \cdot 3 \mathrm{H}_{2} \mathrm{O}$ and $\left[\mathrm{Zn}\left(\mathrm{L}^{1}\right)\left(\mathrm{NO}_{3}\right)_{2}\right] \cdot 4.5 \mathrm{H}_{2} \mathrm{O}$ complexes of the $\mathrm{L}^{1}$ ligand are attributable to the related molecular ions $m / z: 516.20[\mathrm{M}-\mathrm{H}]^{-}, 515.20[\mathrm{M}+\mathrm{H}]^{+}, 517.20[\mathrm{M}-2 \mathrm{H}]^{2-}$ and $517.21[\mathrm{M}+\mathrm{H}]^{+}$, respectively. The mass spectra peaks of the other $\mathrm{L}^{2}$ complexes $\left[\mathrm{Cu}_{2}\left(\mathrm{~L}^{2}\right)(\mathrm{OAc})_{4}\right] \cdot 2 \mathrm{H}_{2} \mathrm{O} \cdot 2 \mathrm{DMF}$, $\left[\mathrm{Cu}\left(\mathrm{L}^{2}\right)_{2}\right] \cdot 2 \mathrm{NO}_{3} \cdot 1.5 \mathrm{DMF} \cdot \mathrm{H}_{2} \mathrm{O}, \quad\left[\mathrm{Zn}\left(\mathrm{L}^{2}\right)_{2}\left(\mathrm{NO}_{3}\right)_{2}\right] \cdot \mathrm{DMF} \quad$ and $\quad\left[\mathrm{Zn}_{2}\left(\mathrm{~L}^{2}\right)(\mathrm{OAc})_{4}\left(\mathrm{H}_{2} \mathrm{O}\right)_{4}\right] \cdot 5 \mathrm{H}_{2} \mathrm{O} \quad$ are attributable to the related molecular ions $m / z: 807.21[\mathrm{M}+\mathrm{H}]^{+}, 838.14[\mathrm{M}+\mathrm{H}]^{+}, 785.32[\mathrm{M}+\mathrm{H}]^{+}$and $545.20\left[\mathrm{M}-2 \mathrm{OAc}^{-}-7 \mathrm{H}_{2} \mathrm{O}\right]^{2+}$, respectively. The observed free ligand $\mathrm{L}^{1}$ peaks for all of the complexes are $m / z: 247.11[\mathrm{~L}+\mathrm{H}]^{+}[38,39]$. The observed free ligand $\mathrm{L}^{2}$ peaks for each two complexes are similarly $m / z$ : $262.08[\mathrm{~L}+\mathrm{H}]^{+}$except for the $\left[\mathrm{Zn}\left(\mathrm{L}^{2}\right)_{2}\left(\mathrm{NO}_{3}\right)_{2}\right] \cdot \mathrm{DMF}$ complex. The highest peaks in the abundance percent were considered in the spectra. 
Single crystals of the complexes could not be isolated from any solutions, thus no definite structure could be described. However, the analytical, spectroscopic and magnetic data enable us to propose the possible structures shown below in Figures 2-9.

\subsection{Biological Evaluation}

The synthesized compounds were screened for their antibacterial activity using Escherichia coli ATCC 25922, Enterococcus faecalis ATCC 29212, Staphylococcus aureus ATCC 25923, and Salmonella typhimurium CCM 583. The results are shown in Table 2. Control experiments were carried out under similar conditions using ampicillin as standard. The inhibition zone measurements in $\mathrm{mm}$ show that the compounds $\left[\mathrm{Zn}\left(\mathrm{L}^{1}\right)(\mathrm{OAc})_{2}\left(\mathrm{H}_{2} \mathrm{O}\right)_{2}\right] \cdot 3 \mathrm{H}_{2} \mathrm{O},\left[\mathrm{Cu}\left(\mathrm{L}^{2}\right)_{2}\right] \cdot 2 \mathrm{NO}_{3} \cdot 1.5 \mathrm{DMF} \cdot \mathrm{H}_{2} \mathrm{O}$ and $\left[\mathrm{Zn}_{2}\left(\mathrm{~L}^{2}\right)(\mathrm{OAc})_{4}\left(\mathrm{H}_{2} \mathrm{O}\right)_{4}\right] \cdot 5 \mathrm{H}_{2} \mathrm{O}$ are more active than other tested compounds against the test bacteria. The other complexes $\left[\mathrm{Zn}\left(\mathrm{L}^{1}\right)\left(\mathrm{NO}_{3}\right)_{2}\right] \cdot 4.5 \mathrm{H}_{2} \mathrm{O},\left[\mathrm{Cu}\left(\mathrm{L}^{1}\right)(\mathrm{OAc})_{2}\right] \cdot 5 \mathrm{H}_{2} \mathrm{O},\left[\mathrm{Cu}\left(\mathrm{L}^{1}\right)\left(\mathrm{NO}_{3}\right) \mathrm{H}_{2} \mathrm{O}\right] \cdot \mathrm{NO}_{3} \cdot 3.5 \mathrm{H}_{2} \mathrm{O}$, $\left[\mathrm{Zn}\left(\mathrm{L}^{2}\right)_{2}\left(\mathrm{NO}_{3}\right)_{2}\right] \cdot \mathrm{DMF}$ and $\left[\mathrm{Cu}_{2}\left(\mathrm{~L}^{2}\right)(\mathrm{OAc})_{4}\right] \cdot 2 \mathrm{H}_{2} \mathrm{O} \cdot 2 \mathrm{DMF}$ did not show antibacterial activity against test microorganisms like Escherichia coli ATCC 25922, Enterococcus faecalis ATCC 29212, Staphylococcus aureus ATCC 25923, and Salmonella typhimurium CCM 583.

Table 2. Antibacterial activity against test bacteria of the novel cyclohexane-1,3-dione ligands and their metal complexes.

\begin{tabular}{lcccc}
\hline \multirow{2}{*}{ Chemicals } & $\begin{array}{c}\text { Escherichia coli } \\
\text { ATCC 25922 }\end{array}$ & $\begin{array}{c}\text { Enterococcus faecalis } \\
\text { ATCC 29212 }\end{array}$ & $\begin{array}{c}\text { Staphylococcus aureus } \\
\text { ATCC 25923 }\end{array}$ & $\begin{array}{c}\text { Salmonella typhimurium } \\
\text { CCM 583 }\end{array}$ \\
\cline { 2 - 5 } & \multicolumn{5}{c}{ Zone Diameter (mm) (blank disk diameter, 6 mm) } \\
\hline$\left[\mathrm{Cu}\left(\mathrm{L}^{1}\right)(\mathrm{OAc})_{2}\right] \cdot 5 \mathrm{H}_{2} \mathrm{O}$ & 0 & 0 & 0 & 0 \\
{$\left[\mathrm{Cu}\left(\mathrm{L}^{1}\right)\left(\mathrm{NO}_{3}\right) \mathrm{H}_{2} \mathrm{O}\right] \cdot \mathrm{NO}_{3} \cdot 3.5 \mathrm{H}_{2} \mathrm{O}$} & 0 & 0 & 0 & 0 \\
{$\left[\mathrm{Cu}_{2}\left(\mathrm{~L}^{2}\right)(\mathrm{OAc})_{4}\right] \cdot 2 \mathrm{H}_{2} \mathrm{O} \cdot 2 \mathrm{DMF}$} & 0 & 0 & 0 & 0 \\
{$\left[\mathrm{Cu}\left(\mathrm{L}^{2}\right)_{2}\right] \cdot 2 \mathrm{NO}_{3} \cdot 1.5 \mathrm{DMF} \cdot \mathrm{H}_{2} \mathrm{O}$} & 0 & 0 & 11 & 7 \\
{$\left[\mathrm{Zn}\left(\mathrm{L}^{2}\right)\left(\mathrm{NO}_{3}\right)_{2}\right] \cdot 4.5 \mathrm{H}_{2} \mathrm{O}$} & 0 & 0 & 0 & 0 \\
{$\left[\mathrm{Zn}\left(\mathrm{L}^{2}\right)\left(\mathrm{OAc}_{2}\right)_{2}\left(\mathrm{H}_{2} \mathrm{O}\right)_{2}\right] \cdot 3 \mathrm{H}_{2} \mathrm{O}$} & 10 & 0 & 11 & 8 \\
{$\left[\mathrm{Zn}\left(\mathrm{L}^{2}\right)_{2}\left(\mathrm{NO}_{3}\right)_{2}\right] \cdot \mathrm{DMF}$} & 0 & 0 & 0 & 0 \\
{$\left[\mathrm{Zn} 2\left(\mathrm{~L}^{2}\right)(\mathrm{OAc})_{4}\left(\mathrm{H}_{2} \mathrm{O}\right)_{4}\right] \cdot 5 \mathrm{H}_{2} \mathrm{O}$} & 0 & 0 & 7 & 0 \\
$\mathrm{Ampicillin}$ & 16 & 22 & 32 & 26 \\
\hline
\end{tabular}

\section{Experimental Section}

\subsection{Reagents and Instrumentation}

All solvents used were of analytical grade and no further purifications were performed. The metal salts $\mathrm{Zn}\left(\mathrm{NO}_{3}\right)_{2} \cdot 6 \mathrm{H}_{2} \mathrm{O}, \mathrm{Cu}\left(\mathrm{NO}_{3}\right)_{2} \cdot 2 \mathrm{H}_{2} \mathrm{O}, \mathrm{Zn}(\mathrm{OAc})_{2} \cdot 2 \mathrm{H}_{2} \mathrm{O}, \mathrm{Cu}(\mathrm{OAc})_{2} \cdot \mathrm{H}_{2} \mathrm{O}$ and starting materials for the ligands were Merck (Darmstadt, Germany), Aldrich (St. Louis, MO, USA), and Alfa Aesar (Karlsruh, Germany) products.

Elemental analyses were carried out on a CHNS-O model 932 elemental analyzer (Leco, St. Joseph, MI, USA). ${ }^{1} \mathrm{H}-\mathrm{NMR}$ and ${ }^{13} \mathrm{C}-\mathrm{NMR}$ spectra were recorded using a model DPX-400 MHz FT spectrometer (Bruker GmbH, Billerica, MA, USA). IR spectra were recorded on a Precisely Spectrum One spectrometer (Perkin Elmer, Akron, OH, USA) using $\mathrm{KBr}$ discs in the wavenumber range of $4000-400 \mathrm{~cm}^{-1}$. 
Electronic spectra studies were conducted on a model UV-1700 spectrophotometer (Shimadzu, Kyoto, Japan) in the wavelength 1100-200 nm. Magnetic susceptibility measurements were performed using the standard Gouy tube technique. $\mathrm{Hg}\left[\mathrm{Co}(\mathrm{SCN})_{4}\right]$ was used for calibration calibrate. LC/MS-API-ES mass spectra were recorded using an Agilent model 1100 MSD mass spectrophotometer (Minneapolis, MN, USA). Thermogravimetric analysis (TGA) and differential thermal analysis (DTA) were carried out in nitrogen atmosphere with a heating rate of $10^{\circ} \mathrm{C} \cdot \mathrm{min}^{-1}$ using a Shimadzu DTG-60 AH thermal analyzer.

\subsection{Antibacterial Activity Studies}

The disk diffusion method was used for determining the antibacterial activity of ligands and complexes. Antibacterial activity against Enterococcus faecalis ATCC 29212, Staphylococcus aureus ATCC 25923, Escherichia coli ATCC 25922, and Salmonella typhimurium CCM 583 was investigated. Mueller-Hinton agar (Oxoid Ltd., Basingstoke, Hampshire, UK) was used for all bacterial strains, except for Enterococcus faecalis ATCC 29212 for which Mueller Hinton agar with 5\% defibrinated sheep blood was used. The media were melted at $100{ }^{\circ} \mathrm{C}$, autoclaved at $121{ }^{\circ} \mathrm{C}$ for $15 \mathrm{~min}$, cooled $45^{\circ} \mathrm{C}$ to $50^{\circ} \mathrm{C}$ and were poured into plates of $9 \mathrm{~cm}$ diameter in quantities of $20 \mathrm{~mL}$, and left on a flat surface to solidify and the surface of media was dried at $37{ }^{\circ} \mathrm{C}$. Then, preparation of the inoculums was used for colony growth method in Mueller-Hinton broth to a turbidity equivalent to a 0.5 McFarland $\left(10^{8} \mathrm{cfu} \cdot \mathrm{mL}^{-1}\right)$ standard. The organisms were streaked on Petri dishes using sterile cotton swab. The surface of the media was allowed to dry 3-5 min at room temperature. The $10 \mathrm{mg} \cdot \mathrm{mL}^{-1}$ (in DMSO, Merck), of compound impregnated blank discs (Oxoid Ltd.) were applied to the surface of inoculated plates. The Mueller-Hinton agar plates were incubated at $35 \pm 2{ }^{\circ} \mathrm{C}$ for $18-24 \mathrm{~h}$. The plates were examined and the diameter of the inhibition zone was measured by surrounding discs. The antibiotic ampicillin (10 $\mu \mathrm{g}$, Oxoid) was used as the standard [40,41].

\subsection{Synthesis of the Ligands $L^{1}$ and $L^{2}$}

A hydrochloric acid solution $(2.5 \mathrm{~mL})$ of 3-methoxyaniline $(1.23 \mathrm{~g}, 10 \mathrm{mmol})$ and an aqueous solution $(10 \mathrm{~mL})$ of sodium nitrite $(0.69 \mathrm{~g}, 10 \mathrm{mmol})$ were mixed and stirred at $273 \mathrm{~K}$ for $1 \mathrm{~h}$. To this solution, an ethanol solution ( $10 \mathrm{~mL})$ of the coupling component cyclohexane-1,3-dione (1.12 $\mathrm{g}, 10 \mathrm{mmol})$ was added and the stirring was continued at $273 \mathrm{~K}$ for $4 \mathrm{~h}$. The resulting product was filtered and washed with water, dried and crystallized from ethanol (yield 77\%). A similar synthesis was performed for $\mathrm{L}^{2}$ using 3-nitroaniline (1.38 g, $10 \mathrm{mmol}$ ) instead of 3-methoxyaniline.

$\mathbf{L}^{1}$; Yield: (77.0\%). FW: $246.10 \mathrm{~g} \cdot \mathrm{mol}^{-1}$. m.p.: $330{ }^{\circ} \mathrm{C}$. Anal. Calcd. for $\mathrm{C}_{13} \mathrm{H}_{14} \mathrm{~N}_{2} \mathrm{O}_{3}$ : C, 63.40, H, 5.73, N, 11.38. Found: C, 64.00, H, 5.84, N, 11.49. Selected IR data $\left(\mathrm{KBr}, v_{\mathrm{cm}}^{-1}\right): 2955-3500(\mathrm{~N}-\mathrm{H})$, 1696, $1671(\mathrm{C}=\mathrm{O}), 1592(\mathrm{C}=\mathrm{N}), 1505(\mathrm{C}=\mathrm{C}), 1025(\mathrm{~N}-\mathrm{N})$. UV-VIS (in DMF): $\lambda_{\max }\left(\varepsilon, \mathrm{L} \cdot \mathrm{mol}^{-1} \cdot \mathrm{cm}^{-1}\right)$ 218, 242 (1453, 1613), 316-393 (2106-2620) nm; ${ }^{1} \mathrm{H}-\mathrm{NMR}$ (400 MHz, DMSO-d6): $\delta 15.00$ (s, 1H, $\mathrm{NH}), 7.00-7.80(\mathrm{~m}, 4 \mathrm{H}, \mathrm{Ar}-\mathrm{CH}), 2.00\left(4 \mathrm{H}, \mathrm{CH}_{2}\right), 2.70\left(2 \mathrm{H}, \mathrm{CH}_{2}\right), 4.00\left(\mathrm{~s}, 3 \mathrm{H}, \mathrm{CH}_{3}\right) .{ }^{13} \mathrm{C}-\mathrm{NMR}$ (DMSO-d6): $\delta 30.12\left(\mathrm{CH}_{3}\right), 55.87\left(3 \mathrm{CH}_{2}\right), 119.13(\mathrm{Ar}-\mathrm{H}), 122.65(\mathrm{Ar}-\mathrm{H}), 132.64(\mathrm{Ar}-\mathrm{NH}-\mathrm{N}), 147.00$ $(\mathrm{C}=\mathrm{N}), 197.00(\mathrm{C}=\mathrm{O}), 197.10(\mathrm{C}=\mathrm{O})$. MS [ES]: $m / z 247[\mathrm{M}+\mathrm{H}]^{+}$. Color: Brown. 
$\mathbf{L}^{2}$; Yield: (79.0\%). FW: $261.10 \mathrm{~g} \cdot \mathrm{mol}^{-1}$. m.p.: $332{ }^{\circ} \mathrm{C}$. Anal. Calcd. for $\mathrm{C}_{12} \mathrm{H}_{11} \mathrm{~N}_{3} \mathrm{O}_{4}$ : C, 55.15, H, 4.21, N, 16.08. Found: C, 55.00, H, 4.84, N, 16.49. Selected IR data $\left(\mathrm{KBr}, v \mathrm{~cm}^{-1}\right): 3500-3100(\mathrm{~N}-\mathrm{H})$, $1686(\mathrm{C}=\mathrm{O}), 1614(\mathrm{C}=\mathrm{N}), 1527(\mathrm{C}=\mathrm{C}), 1010(\mathrm{~N}-\mathrm{N})$. UV-VIS (in DMF): $\lambda_{\max }\left(\varepsilon, \mathrm{L} \cdot \mathrm{mol}^{-1} \cdot \mathrm{cm}^{-1}\right.$ ) 218,240 (1453, 1612), 316-393 (2106-2620) nm; ${ }^{1} \mathrm{H}-\mathrm{NMR}$ (400 MHz, DMSO-d6): $\delta 14.56$ (s, 1H, $\mathrm{NH}), 7.62-8.02(\mathrm{~m}, 4 \mathrm{H}, \mathrm{Ar}-\mathrm{CH}), 2.60\left(4 \mathrm{H}, \mathrm{CH}_{2}\right), 2.66\left(2 \mathrm{H}, \mathrm{CH}_{2}\right) .{ }^{13} \mathrm{C}-\mathrm{NMR}$ (DMSO-d6): $\delta 30.12$ $\left(\mathrm{CH}_{2}\right), 52.37\left(2 \mathrm{CH}_{2}\right), 118.69(\mathrm{Ar}-\mathrm{H}), 120.75(\mathrm{Ar}-\mathrm{H}), 131.47(\mathrm{Ar}-\mathrm{NH}-\mathrm{N}), 143.05(\mathrm{C}=\mathrm{N}), 193.37$ $(\mathrm{C}=\mathrm{O}), 197.55(\mathrm{C}=\mathrm{O})$. MS [ES]: $m / z 262.08[\mathrm{M}+\mathrm{H}]^{+}$. Color: Orange.

\subsection{Synthesis of the Zn(II) and Cu(II) Complexes of the Ligands}

$\mathbf{L}^{\mathbf{1}}$ (1 g, $\left.4 \mathrm{mmol}\right)$ was dissolved in absolute methanol $(15 \mathrm{~mL})$. A solution of $4.0 \mathrm{mmol}$ of metal salts $\left[\mathrm{Zn}\left(\mathrm{NO}_{3}\right)_{2} \cdot 6 \mathrm{H}_{2} \mathrm{O}(1.19 \mathrm{~g}), \mathrm{Cu}\left(\mathrm{NO}_{3}\right)_{2} \cdot 2 \mathrm{H}_{2} \mathrm{O}(0.94 \mathrm{~g}), \mathrm{Zn}(\mathrm{OAc})_{2} \cdot 2 \mathrm{H}_{2} \mathrm{O}(0.88 \mathrm{~g})\right.$, and $\mathrm{Cu}(\mathrm{OAc})_{2} \cdot \mathrm{H}_{2} \mathrm{O}$ $(0.80 \mathrm{~g})]$ in an absolute mixture of methanol and DMF $(10 \mathrm{~mL})$ was added drop wise over $15 \mathrm{~min}$. with continuous stirring at room temperature. The reaction mixtures were then further stirred for $6 \mathrm{~h}$ at $80{ }^{\circ} \mathrm{C}$. The resulting precipitates were filtered, washed with absolute ether and dried at room temperature. Similar syntheses were performed for the $\mathrm{L}^{2}$ complexes using $\mathrm{Zn}\left(\mathrm{NO}_{3}\right)_{2} \cdot 6 \mathrm{H}_{2} \mathrm{O}(0.60 \mathrm{~g}, 2 \mathrm{mmol})$, $\mathrm{Cu}\left(\mathrm{NO}_{3}\right)_{2} \cdot 2 \mathrm{H}_{2} \mathrm{O}(0.48 \mathrm{~g}, 2 \mathrm{mmol}), \mathrm{Zn}(\mathrm{OAc})_{2} \cdot 2 \mathrm{H}_{2} \mathrm{O}(0.89 \mathrm{~g}, 4 \mathrm{mmol})$, and $\mathrm{Cu}(\mathrm{OAc})_{2} \cdot \mathrm{H}_{2} \mathrm{O}(1.60 \mathrm{~g}$, $8 \mathrm{mmol}), \mathrm{L}^{2}(1 \mathrm{~g}, 4 \mathrm{mmol})$.

$\left[\mathrm{Cu}\left(\mathrm{L}^{1}\right)(\mathrm{OAc})_{2}\right] \cdot 5 \mathrm{H}_{2} \mathrm{O}$ (Figure 2): Yield: (78.0\%). FW: $517.64 \mathrm{~g} \cdot \mathrm{mol}^{-1}$. m.p.: $>400{ }^{\circ} \mathrm{C}$. $\mu_{\text {eff }}(\mathrm{B} . \mathrm{M}$.): 1.61. Anal. Calcd. for $\mathrm{C}_{17} \mathrm{H}_{30} \mathrm{~N}_{2} \mathrm{O}_{12} \mathrm{Cu}$ : C, 39.41, H, 5.80, N, 5.41. Found: C, 39.50, H, 5.77, N, 5.39. Selected IR data $\left(\mathrm{KBr}, v \mathrm{~cm}^{-1}\right): 3468(\mathrm{O}-\mathrm{H}), 3450(\mathrm{~N}-\mathrm{H}), 1665(\mathrm{C}=\mathrm{O}), 1558(\mathrm{C}=\mathrm{N}), 1507(\mathrm{C}=\mathrm{C}), 1044$

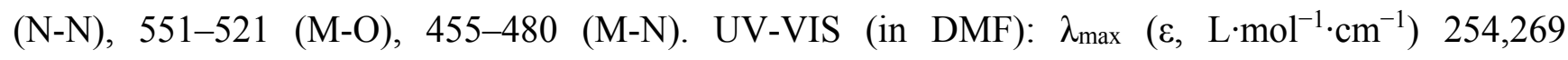
(1693-1793), 414 (266), 580 (386) nm; MS [ES]: $m / z 516.64$ (calc), 516.20 (found) [M-H]-, 247.10 (calc.), 247.11 (found) $[\mathrm{L}+\mathrm{H}]^{+}$. Color: Dark black.

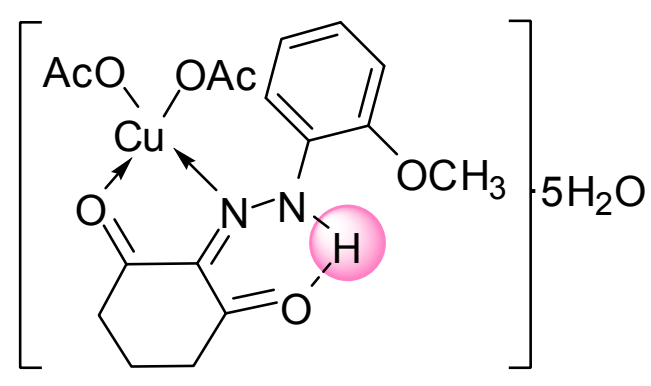

Figure 2. Structure of $\left[\left(\mathrm{CuL}^{1}\right)(\mathrm{OAc})_{2}\right] \cdot 5 \mathrm{H}_{2} \mathrm{O}$ complex.

$\left[\mathrm{Cu}\left(\mathrm{L}^{1}\right)\left(\mathrm{NO}_{3}\right) \mathrm{H}_{2} \mathrm{O}\right] \cdot \mathrm{NO}_{3} \cdot 3.5 \mathrm{H}_{2} \mathrm{O}$ (Figure 3): Yield: (80.0\%). FW: $514.64 \mathrm{~g} \cdot \mathrm{mol}^{-1}$. m.p.: $>390{ }^{\circ} \mathrm{C}$. $\mu_{\text {eff }}$ (B.M.): 1.72. Anal. Calcd. for $\mathrm{C}_{13} \mathrm{H}_{16} \mathrm{~N}_{4} \mathrm{O}_{10} \mathrm{Cu} \cdot 3.5 \mathrm{H}_{2} \mathrm{O}: \mathrm{C}, 30.31, \mathrm{H}, 4.47, \mathrm{~N}, 10.88$. Found: C, 30.45, H, 4.55, N, 10.87. Selected IR data $\left(\mathrm{KBr}, v \mathrm{~cm}^{-1}\right): 3545(\mathrm{O}-\mathrm{H}), 3313(\mathrm{~N}-\mathrm{H}), 1663(\mathrm{C}=\mathrm{O}), 1593$ $(\mathrm{C}=\mathrm{N}), 1509(\mathrm{C}=\mathrm{C}), 1041(\mathrm{~N}-\mathrm{N}), 585(\mathrm{M}-\mathrm{O}), 491(\mathrm{M}-\mathrm{N})$. UV-VIS (in DMF): $\lambda_{\max }\left(\varepsilon, \mathrm{L} \cdot \mathrm{mol}^{-1} \cdot \mathrm{cm}^{-1}\right)$ 254-295, 353, 393 (1693-1966, 2353, 262), 428-450 (285-300) nm; MS [ES]: m/z 515.64 (calc), 515.20 (found) $[\mathrm{M}+\mathrm{H}]^{+}, 247.10$ (calc.), 247.11 (found) $[\mathrm{L}+\mathrm{H}]^{+}$. Color: Dark green. 


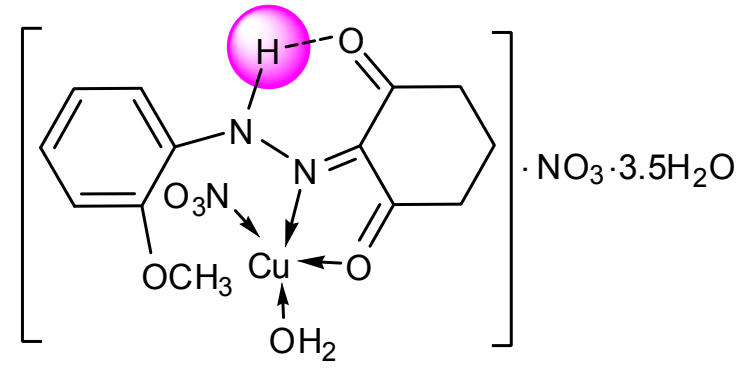

Figure 3. Structure of $\left[\mathrm{Cu}\left(\mathrm{L}^{1}\right)\left(\mathrm{NO}_{3}\right) \mathrm{H}_{2} \mathrm{O}\right] \mathrm{NO}_{3} \cdot 3.5 \mathrm{H}_{2} \mathrm{O}$ complex.

[Zn $\left.\left(\mathrm{L}^{1}\right)\left(\mathrm{NO}_{3}\right)_{2}\right] \cdot 4.5 \mathrm{H}_{2} \mathrm{O}$ (Figure 4): Yield: (75.0\%). FW: $516.37 \mathrm{~g} \cdot \mathrm{mol}^{-1}$. m.p.: $330{ }^{\circ} \mathrm{C} . \mu_{\mathrm{eff}}($ B.M.): Dia. Anal. Calcd. for $\mathrm{C}_{13} \mathrm{H}_{14} \mathrm{~N}_{4} \mathrm{O}_{9} \mathrm{Zn} \cdot 4.5 \mathrm{H}_{2} \mathrm{O}: \mathrm{C}, 30.21, \mathrm{H}, 4.45, \mathrm{~N}, 10.84$. Found: $\mathrm{C}, 30.22, \mathrm{H}, 4.38, \mathrm{~N}$, 10.86. Selected IR data $\left(\mathrm{KBr}, v \mathrm{~cm}^{-1}\right): 3496(\mathrm{O}-\mathrm{H}), 3317(\mathrm{~N}-\mathrm{H}), 1671(\mathrm{C}=\mathrm{O}), 1590(\mathrm{C}=\mathrm{N}), 1504$ $(\mathrm{C}=\mathrm{C}), 1042(\mathrm{~N}-\mathrm{N}), 543-514(\mathrm{M}-\mathrm{O}), 475(\mathrm{M}-\mathrm{N})$. UV-VIS (in DMF): $\lambda_{\max }\left(\varepsilon, \mathrm{L} \cdot \mathrm{mol}^{-1} \cdot \mathrm{cm}^{-1}\right)$ 257-308 (1713-2053), 357 (2380) nm; MS [ES]: m/z 517.37 (calc), 517.21 (found) $[\mathrm{M}+\mathrm{H}]^{+}, 247.10$ (calc.), 247.11 (found) $[\mathrm{L}+\mathrm{H}]^{+}$. Color: Brown.

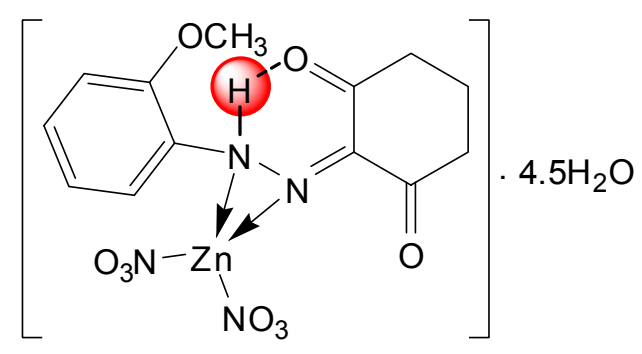

Figure 4. Structure of $\left[\mathrm{Zn}\left(\mathrm{L}^{1}\right)\left(\mathrm{NO}_{3}\right)_{2}\right] \cdot 4.5 \mathrm{H}_{2} \mathrm{O}$ complex.

[Zn $\left.\left(\mathrm{L}^{1}\right)(\mathrm{OAc})_{2}\left(\mathrm{H}_{2} \mathrm{O}\right)_{2}\right] \cdot 3 \mathrm{H}_{2} \mathrm{O}$ (Figure 5): Yield: (75.0\%). FW: $519.47 \mathrm{~g} \cdot \mathrm{mol}^{-1}$. m.p.: $320{ }^{\circ} \mathrm{C}$. $\mu_{\text {eff }}(\mathrm{B} . \mathrm{M}$.): Dia. Anal. Calcd. for $\mathrm{C}_{17} \mathrm{H}_{30} \mathrm{~N}_{2} \mathrm{O}_{12} \mathrm{Zn}$ : C, 39.27, H, 5.78, N, 5.39. Found: C, 39.31, H, 5.76, N, 5.40. Selected IR data $\left(\mathrm{KBr}, v \mathrm{~cm}^{-1}\right): 3400(\mathrm{O}-\mathrm{H})$, Broad $(\mathrm{N}-\mathrm{H}), 1671(\mathrm{C}=\mathrm{O}), 1555(\mathrm{C}=\mathrm{N}), 1506(\mathrm{C}=\mathrm{C})$, $1042(\mathrm{~N}-\mathrm{N}), 540-513(\mathrm{M}-\mathrm{O}), 474(\mathrm{M}-\mathrm{N})$. UV-VIS (in DMF): $\lambda_{\max }\left(\varepsilon, \mathrm{L} \cdot \mathrm{mol}^{-1} \cdot \mathrm{cm}^{-1}\right) \quad 357-399$ (2380-2660) nm; MS [ES]: $m / z 517.47$ (calc), 517.20 (found) $[\mathrm{M}-2 \mathrm{H}]^{2-}, 247.10$ (calc.), 247.11 (found) $[\mathrm{L}+\mathrm{H}]^{+}$. Color: Light brown.

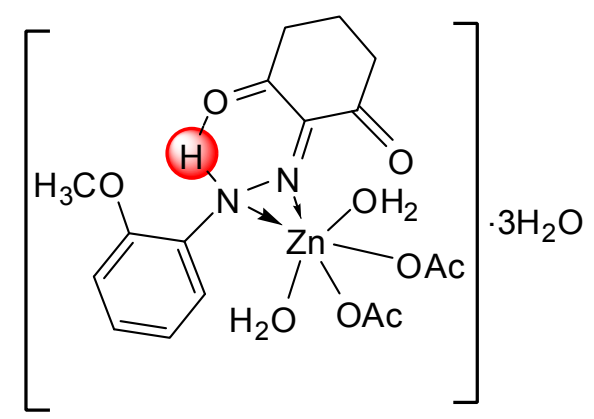

Figure 5. Structure of $\left[\mathrm{Zn}\left(\mathrm{L}^{1}\right)(\mathrm{OAc})_{2}\left(\mathrm{H}_{2} \mathrm{O}\right)_{2}\right] \cdot 3 \mathrm{H}_{2} \mathrm{O}$ complex.

[Cu2 $\left.\left(\mathrm{L}^{2}\right)(\mathrm{OAc})_{4}\right] \cdot 2 \mathrm{H}_{2} \mathrm{O} \cdot 2 \mathrm{DMF}$ (Figure 6): Yield: (76.0\%). FW: $806.18 \mathrm{~g} \cdot \mathrm{mol}^{-1}$. m.p.: $>400$. $\mu_{\text {eff }}(\mathrm{B} . \mathrm{M}$.): 1.66. Anal. Calcd. for $\mathrm{C}_{26} \mathrm{H}_{41} \mathrm{~N}_{5} \mathrm{O}_{16} \mathrm{Cu}_{2}$ : C, 38.70, H, 5.09, N, 8.68. Found: C, 38.57, H, 5.12, N, 8.73. 
Selected IR data (KBr, $\left.v \mathrm{~cm}^{-1}\right): 3436(\mathrm{O}-\mathrm{H}), 3320(\mathrm{~N}-\mathrm{H}), 1660(\mathrm{C}=\mathrm{O}), 1584(\mathrm{C}=\mathrm{N}), 1528(\mathrm{C}=\mathrm{C}), 1030$ $(\mathrm{N}-\mathrm{N}), 571-518(\mathrm{M}-\mathrm{O}), 466(\mathrm{M}-\mathrm{N})$. UV-VIS (in DMF): $\lambda_{\max }\left(\varepsilon, \mathrm{L} \cdot \mathrm{mol}^{-1} \cdot \mathrm{cm}^{-1}\right)$ 257-375 (1713-2500), 454 (302), 600 (66) nm; MS [ES]: $m / z 807.18$ (calc), 807.21 (found) [M+H] $]^{+}, 542.18$ (calc), 542.14 (found) $\left[\mathrm{M}-2 \mathrm{AcO}^{-}-2 \mathrm{H}_{2} \mathrm{O}\right]^{2+}$ (Cationic complex) 262.10 (calc.), 262.08 (found) $[\mathrm{L}+\mathrm{H}]^{+}$. Color: Dark brown.

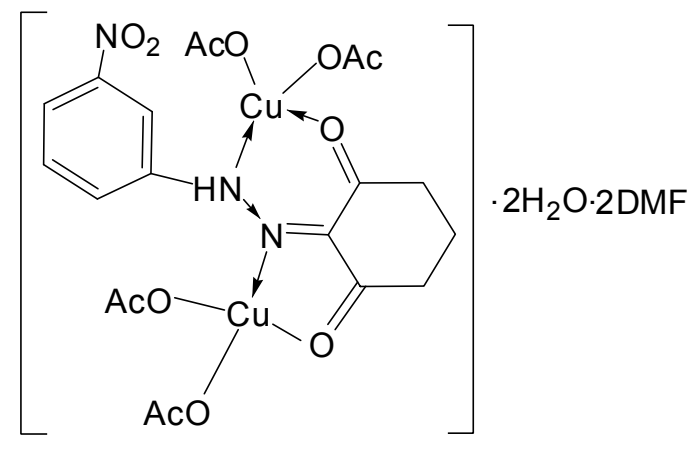

Figure 6. Structure of $\left[\mathrm{Cu}_{2}\left(\mathrm{~L}^{2}\right)(\mathrm{OAc})_{4}\right] \cdot 2 \mathrm{H}_{2} \mathrm{O} \cdot 2 \mathrm{DMF}$ complex.

$\left[\mathrm{Cu}\left(\mathrm{L}^{2}\right)_{2}\right] \cdot 2 \mathrm{NO}_{3} \cdot 1.5 \mathrm{DMF} \cdot \mathrm{H}_{2} \mathrm{O}$ (Figure 7): Yield: (72.0\%). FW: $837.24 \mathrm{~g} \cdot \mathrm{mol}^{-1} \cdot \mathrm{m} . \mathrm{p} .:>400$. $\mu_{\text {eff( }}$ (B.M.): 2.20. Anal. Calcd. for $\mathrm{C}_{24} \mathrm{H}_{24} \mathrm{~N}_{8} \mathrm{O}_{15} \mathrm{Cu} \cdot 1.5 \mathrm{DMF}$ : C, 40.85, H, 3.88, N, 15.89. Found: C, 40.86, H, 3.92, $\mathrm{N}$, 15.91. Selected IR data $\left(\mathrm{KBr}, v \mathrm{~cm}^{-1}\right): 3441(\mathrm{O}-\mathrm{H}), 3367(\mathrm{~N}-\mathrm{H}), 1663(\mathrm{C}=\mathrm{O}), 1609(\mathrm{C}=\mathrm{N}), 1528$ $(\mathrm{C}=\mathrm{C}), 1023(\mathrm{~N}-\mathrm{N}), 574-510(\mathrm{M}-\mathrm{O}), 491-466(\mathrm{M}-\mathrm{N})$. UV-VIS (in DMF): $\lambda_{\max }\left(\varepsilon, \mathrm{L}^{\mathrm{mol}} \mathrm{m}^{-1} \cdot \mathrm{cm}^{-1}\right)$ 254-376 (1693-3760), 470 (313) nm; MS [ES]: $m / z 838.24$ (calc), 838.14 (found) $[\mathrm{M}+\mathrm{H}]^{+}, 574.74$

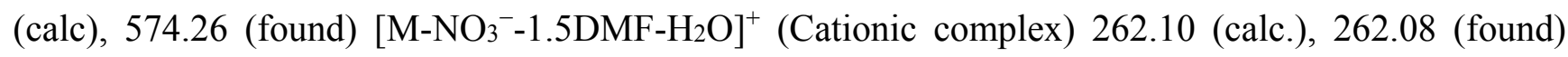
$[\mathrm{L}+\mathrm{H}]^{+}$. Color: Green.

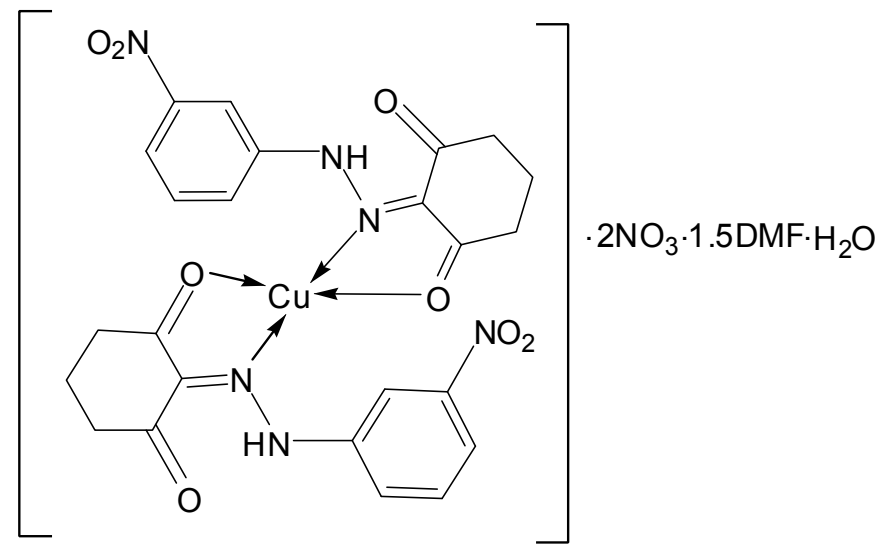

Figure 7. Structure of $\left[\mathrm{Cu}\left(\mathrm{L}^{2}\right)_{2}\right] \cdot 2 \mathrm{NO}_{3} \cdot 1.5 \mathrm{DMF} \cdot \mathrm{H}_{2} \mathrm{O}$ complex.

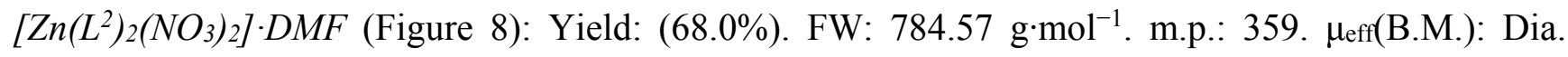
Anal. Calcd. for $\mathrm{C}_{24} \mathrm{H}_{22} \mathrm{~N}_{7} \mathrm{O}_{16} \mathrm{Zn}$ : C, 41.30, H, 3.70, N, 14.28. Found: C, 40.33, H, 3.72, N, 14.26. Selected IR data $\left(\mathrm{KBr}, v \mathrm{~cm}^{-1}\right): 3300(\mathrm{~N}-\mathrm{H}), 1662(\mathrm{C}=\mathrm{O}), 1606(\mathrm{C}=\mathrm{N}), 1514(\mathrm{C}=\mathrm{C}), 1020(\mathrm{~N}-\mathrm{N})$, 580-520 (M-O), 473 (M-N). UV-VIS (in DMF): $\lambda_{\max }\left(\varepsilon, \mathrm{L} \cdot \mathrm{mol}^{-1} \cdot \mathrm{cm}^{-1}\right) 357-375(2380-2500) \mathrm{nm}$; MS [ES]: $m / z 785.57$ (calc), 785.32 (found) $[\mathrm{M}+\mathrm{H}]^{+}$. Color: Dark brown. 


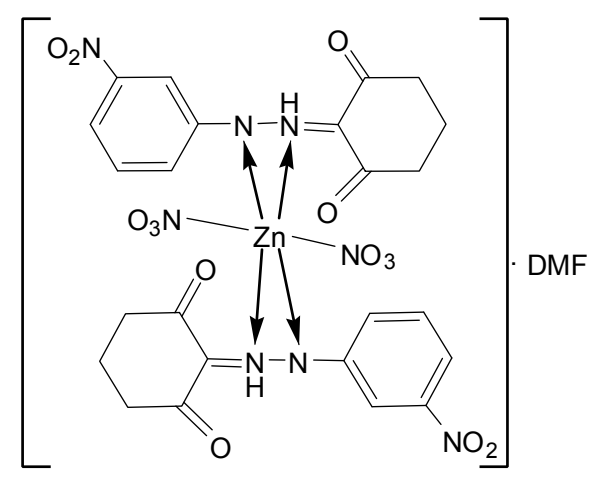

Figure 8. Structure of $\left[\mathrm{Zn}\left(\mathrm{L}^{2}\right)_{2}\left(\mathrm{NO}_{3}\right)_{2}\right] \cdot \mathrm{DMF}$ complex.

[Zn $\left.2\left(\mathrm{~L}^{2}\right)(\mathrm{OAc})_{4}\left(\mathrm{H}_{2} \mathrm{O}\right)_{4}\right] \cdot 5 \mathrm{H}_{2} \mathrm{O}$ (Figure 9): Yield: (64.0\%). FW: $789.74 \mathrm{~g} \cdot \mathrm{mol}^{-1}$. m.p.: 335. $\mu_{\text {eff }}(\mathrm{B} . \mathrm{M}$.$) :$ Dia. Anal. Calcd. for $\mathrm{C}_{20} \mathrm{H}_{41} \mathrm{~N}_{3} \mathrm{O}_{21} \mathrm{Zn}_{2}$ : C, 30.38, H, 5.19, N, 5.31. Found: C, 30.41, H, 5.20, N, 5.34. Selected IR data $\left(\mathrm{KBr}, v \mathrm{~cm}^{-1}\right): 3411(\mathrm{O}-\mathrm{H}),(\mathrm{N}-\mathrm{H})$ broad, $1668(\mathrm{C}=\mathrm{O}), 1607(\mathrm{C}=\mathrm{N}), 1528(\mathrm{C}=\mathrm{C}), 1023$

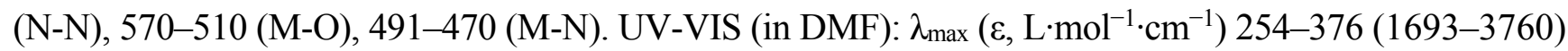
$\mathrm{nm}$; MS [ES]: $m / z 545.84$ (calc), 545.20 (found) $\left[\mathrm{M}-2 \mathrm{AcO}^{-}-7 \mathrm{H}_{2} \mathrm{O}^{2+}\right.$ (Cationic complex) 262.10 (calc.), 262.08 (found) $[\mathrm{L}+\mathrm{H}]^{+}$. Color: Black.

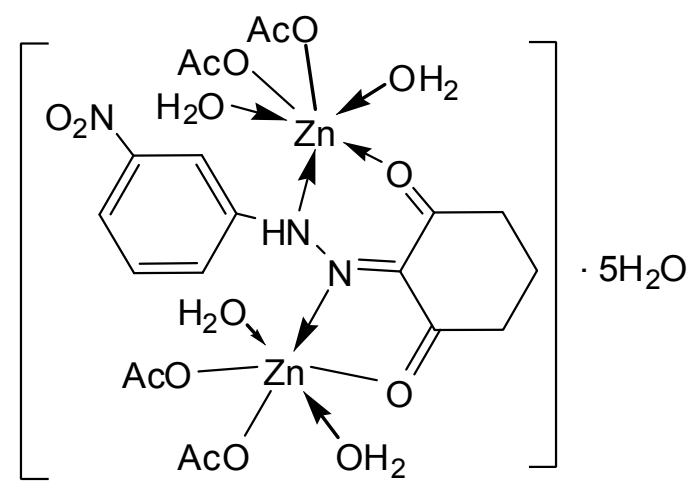

Figure 9. Structure of $\left[\mathrm{Zn}_{2}\left(\mathrm{~L}^{2}\right)(\mathrm{OAc})_{4}\left(\mathrm{H}_{2} \mathrm{O}\right)_{4}\right] \cdot 5 \mathrm{H}_{2} \mathrm{O}$ complex.

\section{Conclusions}

We have prepared two new ligands and their metal complexes. Structures of the ligands and complexes were confirmed by spectral and analytical techniques. Antibacterial activities of the complexes were tested against Escherichia coli ATCC 25922, Enterococcus faecalis ATCC 29212, Staphylococcus aureus ATCC 25923, and Salmonella typhimurium CCM 583, respectively. Some complexes showed average level antibacterial activity against the test bacteria compared to ampicillin, but some of the complexes did not exhibit antibacterial activity against the test microorganisms. For these reasons, these complexes may not be useful for preparing new active agents.

\section{Acknowledgments}

Chemistry Department and Nursing Department of Muş Alparslan University, Muş, Turkey and Chemistry Department of Inönü University, Malatya, Turkey are thanks for their supporting to this research. 


\section{Author Contributions}

Nevin Turan formulated the research idea and participated in the preparation of manuscript; Nevin Turan, Ragip Adigüzel, Naki Çolak and Kenan Buldurun carried out the experimental, interpreted the data and prepared the manuscript; Hanifi Korkoca performed the biological part. All authors have read and approved the final manuscript.

\section{Conflicts of Interest}

We (Nevin Turan, Hanifi Körkoca, Ragıp Adigüzel, Naki Çolak, Kenan Buldurun) declare that there is no conflict of interests regarding the publication of this article.

\section{References}

1. Lee, D.L.; Prisbylla, M.P.; Cromartie, T.H.; Dagarin, D.P.; Howard, S.W.; Provan, W.M.; Ellis, M.K.; Fraser, T.; Mutter, L.C. The discovery and structural requirements of inhibitors of p-hydroxyphenylpyruvatedioxygene. Weed Sci. 1997, 45, 601-609.

2. Lock, E.A.; Ellis, M.K.; Gaskin, P.; Robinson, M.; Auton, T.R.; Provan, W.M.; Smith, L.L.; Prisbylla, M.P.; Mutter, L.C.; Lee, D.L. From toxicological problem to therapeutic use: the discovery of the mode of action of 2-(2-nitro-4-trifluoromethylbenzoyl)-1,3-cyclohexanedione (NTBC), its toxicology and development as a drug. J. Inherit. Metab. Dis. 1998, 21, 498-506.

3. Sethukumar, A.; Arul Prakasam, B. Spectral and cyclic voltammetric studies on some intramolecularly hydrogen bonded arylhydrazones: Crystal and molecular structure of 2-(2-(3nitrophenyl)hydrazono)-5,5-dimethylcyclohexane-1,3-dione. J. Mol. Struct. 2010, 963, 250-257.

4. Dey, K. Schiff bases and their uses. J. Sci. Ind. Res. 1974, 33, 76-97.

5. Nehru, K.; Athappan, P.; Rajagopal, G. Ruthenium(II)/(III) complexes of bidentate acetyl hydrazide Schiff bases. Transit. Metal Chem. 2001, 26, 652-656.

6. Deepa, K.; Aravindakshan, K.K. Synthesis, characterization and antifungal studies of metal complexes of benzoyl- and salicylylhydrazones of $\omega$-bromoacetoacetanilide. Synth. React. Inorg. Met. 2005, 35, 409-416.

7. El-Dissouky, A.; Shuaib, N.M.; Al-Awadi, N.A.; Abbas, A.B.; El-Sherif, A. Synthesis, characterization, potentiometric and thermodynamic studies of transition metal complexes with 1-benzotriazol-1yl-1-[(p-methoxyphenyl)hydrazono]propan-2-one. J. Coord. Chem. 2008, 61, 579-594.

8. Chang, H-L.; Chao, T-Y.; Yang, C-C.; Dai, S.A.; Jeng, R.-J. Second-order nonlinear optical hyperbranched polymers via facile ring-opening addition reaction of azetidine-2,4-dione. Eur. Polym. J. 2007, 43, 3988-3996.

9. Dabbagh, H.A.; Teimouri, A. Insertion reaction of azidosulfonylazo dye with model alicyclic and heterocyclic compounds. Russ. J. Org. Chem. 2008, 44, 1464-1470.

10. Tuncel, M.; Serin, S. Synthesis and characterization of Copper(II), Nickel(II) and Cobalt(II) complexes with azo-linked Schiff base ligands. Synth. React. Inorg. Met. 2005, 35, 203-212.

11. Raval, J.P.; Rai, A.R.; Patel, N.H.; Patel, H.V.; Patel, P.S. Synthesis and in vitro antimicrobial activity of $N^{\prime}$-(4-(arylamino)-6-(pyridin-2-ylamino)-1,3,5-triazin-2-yl)benzohydrazide. Int. J. ChemTech Res. 2009, 1, 616-620. 
12. Kuznik, W.; Kityk, I.V.; Kopylovich, M.N.; Mahmudov, K.T.; Ozga, K.; Lakshminarayana, G.; Pombeiro, A.J.L. Quantum chemical simulations of solvent influence on UV-vis spectra and orbital shapes of azo derivatives of diphenylpropane-1,3-dione. Spectrochim. Acta Part A 2011, $78,1287-1294$.

13. Pulimamidi, R.R.; Addla, S.; Nomula, R.; Pallepogu, R. Synthesis, structure, DNA binding and cleavage properties of ternary amino acid Schiff base-phen/bipy $\mathrm{Cu}(\mathrm{II})$ complexes. J. Inorg. Biochem. 2011, 105, 1603-1612.

14. Bhowon, M.G.; Wah, H.L.K.; Dosieah, A.; Ridana, M.; Ramalingum O.; Lacour, D. Synthesis, characterization, and catalytic activity of metal Schiff base complexes derived from pyrrole-2-carboxyaldehyde. Synth. React. Inorg. Met. 2004, 34, 1-16.

15. Berestovitskaya, V.M.; Selivanova, M.V.; Vakulenko, M.I.; Efremova, I.E.; Berkova, G.A. Reactions of 2-benzylidene-3-methyl-4-nitro-2,5-dihydrothiophene 1,1-dioxide with $\mathrm{CH}$ acids. Russ. J. Org. Chem. 2009, 45, 1814-1817.

16. Abu-El-Wafa, S.M.; El-Wakiel, N.A.; Issa, R.M.; Mansour, R.A. Formation of novel mono- and multi-nuclear complexes of $\mathrm{Mn}(\mathrm{II}), \mathrm{Co}(\mathrm{II})$ and $\mathrm{Cu}(\mathrm{II})$ with bisazo-dianils containing the pyrimidine moiety: Thermal, magnetic and spectral studies. J. Coord. Chem. 2005, 58, 683-694.

17. Anant, P.; Bibhesh, K.S.; Narendar, B.; Devjani, A. Synthesis and Characterization of bioactive Zinc(II) and Cadmium(II) complexes with new Schiff bases derived from 4-nitrobenzaldehyde and acetophenone with ethylenediamine. Spectrochim. Acta Part A 2010, 76, 356-362.

18. Turan, N.; Sekerci, M. Synthesis and spectral studies of novel $\mathrm{Co}(\mathrm{II}), \mathrm{Ni}(\mathrm{II}), \mathrm{Cu}(\mathrm{II}), \mathrm{Cd}(\mathrm{II})$, and Fe(II) metal complexes with $N$-[5'-amino-2,2'-bis(1,3,4-thiadiazole)-5-yl]-2-hydroxybenzaldehyde imine (HL). Spectrosc. Lett. 2009, 42, 258-267.

19. El-Haty, M.T.; Adam, F.A. Chelating properties of heterocyclic Schiff bases derived from 2-amino-5-phenyl-1,3,4-thiadiazole. Bull. Soc. Chim. Fr. 1986, 5, 729-732.

20. Hui, R-H.; Zhou, P.; You, Z.L. Syntheses crystal structures and antibacterial activities of two end-on azido bridged copper(II) complexes with Schiff bases. Indian J. Chem. Sect. A 2009, 48, 1102-1106.

21. Gup, R.; Kirkan, B. Synthesis and spectroscopic studies of Copper(II) and Nickel(II) complexes containing hydrazonic ligands and heterocyclic coligand. Spectrochim. Acta Part A 2005, 62, 1188-1195.

22. Borras, E.; Alzuet, G.; Borras, J.; Serevr-Carrio, J.; Castineiras, A.; Liu-Gonzalez, M.; Sanz-Ruiz, F. Coordination chemistry of sulfamethizole: Crystal structures of [Cu(sulfamethizolate $\left.)_{2}(\text { py })_{2}\left(\mathrm{OH}_{2}\right)\right] \mathrm{H}_{2} \mathrm{O}$, $\left[\mathrm{M}(\text { sulfamethizolate })_{2}(\mathrm{py})_{2}\left(\mathrm{OH}_{2}\right)_{2}\right][\mathrm{M}=\mathrm{Co}$ and $\mathrm{Ni}]$ and $\left\{\mathrm{Cu}(\text { sulfamethizolate })_{2}(\mathrm{DMF})_{2}\right\}$. Polyhedron 2000, 19, 1859-1866.

23. Cao, G.-B. Synthesis, characterization, and crystal structure of a novel trinuclear Schiff base Nickel(II) complex. Synth. React. Inorg. Met. 2007, 37, 639-642.

24. Chandra, S.; Vandana; Kumar, S. Synthesis, spectroscopic, anticancer, antibacterial and antifungal studies of $\mathrm{Ni}(\mathrm{II})$ and $\mathrm{Cu}(\mathrm{II})$ complexes with hydrazine carboxyamide, 2-[3-methyl-2thienylmethylene]. Spectrochim. Acta Part A 2015, 135, 356-363.

25. Şekerci, M.; Alkan, C. The Synthesis and $\mathrm{Co}(\mathrm{II}), \mathrm{Ni}(\mathrm{II}), \mathrm{Cu}(\mathrm{II})$ and $\mathrm{UO}_{2}(\mathrm{VI})$ complexes of 1,2-O-benzal-4-aza-7-aminoheptane. Synth. React. Inorg. Met. 1999, 29, 1685-1697.

26. AbouEl-Enein, S.A.; El-Saied, F.A.; Kasher, T.I.; El-Wardany, A.H. Synthesis and characterization of Iron(III), Manganese(II), Cobalt(II), Nickel(II), Copper(II) and Zinc(II) complexes of 
salicylidene- $N$-anilinoacetohydrazone $\left(\mathrm{H}_{2} \mathrm{~L}^{1}\right)$ and 2-hydroxy-1-naphthylidene- $N$-anilinoacetohydrazone $\left(\mathrm{H}_{2} \mathrm{~L}^{2}\right)$. Spectrochim. Acta Part A 2007, 67, 737-743.

27. Silverstein, R.M.; Bassler, G.C.; Morrill, T.C. Spectrometric Identification of Organic Compounds, 4th ed.; Wiley: New York, NY, USA, 1981.

28. Losada, J.; delPeso I.; Beyer, L. Electrochemical and spectroelectrochemical properties of Copper(II) Schiff-base complexes. Inorg. Chim. Acta 2001, 321, 107-115.

29. Tabassum, S.; Bashar, A.; Arjmand, F.; Siddigi, G. Synthesis and characterization of lanthanide chelates with metal-containing ligands. Synth. React. Inorg. Met. 1997, 27, 487.

30. Nakamoto, K. Infrared Spectra of Inorganic and Coordination Compounds, 3rd ed.; Wiley Inter Science: New York, NY, USA, 1970; pp. 159, 167, 214.

31. Tharmaraj, P.; Kodimunthiri, D.; Prakash P.; Sheela, C.D. Catalytic and biological activity of transition metal complexes of salicylaldiminopropylphosphine. J. Coord. Chem. 2009, 62, 2883-2892.

32. Uçan, S.Y.; Uçan, M. Synthesis and characterization of new Schiff bases and their Cobalt(II), Nickel(II), Copper(II), Zinc(II), Cadmium(II) and Mercury(II) complexes. Synth. React. Inorg. Met. 2005, 35, 417-421.

33. El-Metwally, N.M.; Gabr, I.M.; Shallaby, A.M.; El-Asmy, A.A. Synthesis and spectroscopic characterization of new mono- and binuclear complexes of some $\mathrm{NH}(1)$ thiosemicarbazides. J. Coord. Chem. 2005, 58, 1145-1159.

34. Sönmez, M.; Sekerci, M. The template synthesis, characterization, and thermal investigation of new heterocyclic binucleating Schiff base complexes. Synth. React. Inorg. Met. 2004, 34, 1551-1561.

35. Sekerci, M. Synthesis, magnetospectral, and thermal studies of Cobalt(II), Nickel(II), and Copper(II) Complexes of new asymmetrical 1,2-dihydroxyimino-3,8-diaza-9-phenylnonane. Russ. J. Inorg. Chem. 2000, 45, 1525-1530.

36. Turan, N.; Sekerci, M. Synthesis, characterization and thermal behavior of some Zn(II) complexes with ligands having 1,3,4-thiadiazole moieties. Heteroat. Chem. 2010, 21, 14-23.

37. El-Bindary, A.A.; El-Sonbati, A.Z.; Diab, M.A.; Attallah, M.E. Polymer complexes. LVI. supramolecular architectures consolidated by hydrogen bonding and $\pi-\pi$ Interaction. Spectrochim. Acta Part A 2012, 86, 547-553.

38. Adiguzel, R.; Esener, H.; Ergin, Z.; Aktan, E.; Turan N.; Sekerci, M. Synthesis and structural characterization of bis(2-amino-1,3,4-thiadiazolyl)methane complexes. Asian J. Chem. 2011, 23, 2795-2800.

39. Esener, H.; Adıgüzel, R.; Ergin, Z.; Aktan, E.; Turan N.; Sekerci, M. Synthesis and characterization of novel $\mathrm{Mn}(\mathrm{II}), \mathrm{Co}(\mathrm{II}), \mathrm{Ni}(\mathrm{II})$ and $\mathrm{Cd}(\mathrm{II})$ complexes from 4-(2-nitrophenylazo)1H-pyrazole-3,5-diamine. Adv. Sci. Lett. 2011, 4, 3669-3675.

40. Clinical and Laboratory Standards Institute. Performance Standards for Antimicrobial Disk Susceptibility Tests, 9th ed.; Approved Standard M2-A9; CLSI: Wayne, PA, USA, 2006. 
41. National Committee for Clinical Laboratory Standards. Performance Standards for Antimicrobial Disk Susceptibility Tests, 7th ed.; Approved Standard M2-A7; NCCLS: Wayne, PA, USA, 2000.

Sample Availability: Samples of the newly synthesized compounds are available from the authors.

(C) 2015 by the authors; licensee MDPI, Basel, Switzerland. This article is an open access article distributed under the terms and conditions of the Creative Commons Attribution license (http://creativecommons.org/licenses/by/4.0/). 